\title{
WestVirginiaUniversity
}

THE RESEARCH REPOSITORY @ WVU

Graduate Theses, Dissertations, and Problem Reports

2007

\section{Attitudes of 4-H club leaders toward volunteer training in West Virginia}

Jennifer Post

West Virginia University

Follow this and additional works at: https://researchrepository.wvu.edu/etd

\section{Recommended Citation}

Post, Jennifer, "Attitudes of 4-H club leaders toward volunteer training in West Virginia" (2007). Graduate Theses, Dissertations, and Problem Reports. 2557.

https://researchrepository.wvu.edu/etd/2557

This Thesis is protected by copyright and/or related rights. It has been brought to you by the The Research Repository @ WVU with permission from the rights-holder(s). You are free to use this Thesis in any way that is permitted by the copyright and related rights legislation that applies to your use. For other uses you must obtain permission from the rights-holder(s) directly, unless additional rights are indicated by a Creative Commons license in the record and/ or on the work itself. This Thesis has been accepted for inclusion in WVU Graduate Theses, Dissertations, and Problem Reports collection by an authorized administrator of The Research Repository @ WVU. For more information, please contact researchrepository@mail.wvu.edu. 


\title{
Attitudes of 4-H Club Leaders Toward Volunteer \\ Training in West Virginia
}

\author{
Jennifer Post
}

\begin{abstract}
Thesis submitted to the Davis College of Agriculture, Forestry, and Consumer Sciences at West Virginia University in partial fulfillment of the requirements for the degree of

Master of Science

in Agricultural and Extension Education
\end{abstract}
Harry N. Boone, Jr., Ph.D., Chair Deborah A. Boone, Ph.D. Jean M. Woloshuk, Ed.D.

Division of Resource Management Morgantown, WV 2007

Keywords: Agricultural Education, 4-H, Volunteer Training 


\section{ABSTRACT \\ Attitudes of 4-H Club Leaders Toward Volunteer \\ Training in West Virginia}

\section{Jennifer Post}

Volunteers are essential to the 4-H program. This study was conducted to determine why individuals volunteer for 4-H, how volunteers feel towards the training they are offered, what the training needs of 4-H volunteers were, and the methods $4-\mathrm{H}$ volunteers prefer to receive training. A questionnaire was sent to 260 volunteer club leaders in 27 counties in the state of West Virginia. 4-H volunteers have multiple reasons for being a volunteer club leader including helping people and working with youth. 4-H volunteer club leaders feel that training is important in becoming a leader and that training is for everyone regardless of 4-H background. Volunteers have received training on various topics in the past. Volunteers would like to have additional training in club mechanics, leadership roles, public relations, volunteer leader training, subject matter, leisure education, and skills 4-H youth learn. Volunteers concluded they could learn more from additional training activities to become better volunteers for $4-\mathrm{H}$. 


\section{DEDICATION}

This thesis is dedicated to all of the volunteers that I encountered during the past 15 years I have been involved with $4-\mathrm{H}$ as a member, teen leader, camp counselor, volunteer camping assistant, and volunteer leader. Without your time and talent, the program would not have had the same impact as it has had in my life. May you all continue to "make the best better." 


\section{ACKNOWLEDGEMENTS}

I would like to thank my husband and son for all of the time and patience they have given me during this process. They have had to endure countless hours without me as I have studied and prepared to graduate with my degree. I would like to thank my advisor, Dr. Harry Boone, Jr., Ph.D, for the constant support, help, and feedback throughout this process. I would like to thank the rest of my committee, Deborah A. Boone, Ph.D. and Jean M. Woloshuk, Ed.D., for the enthusiasm they showed me as I prepared to embark on this research topic. I would also like to thank all of the 4-H volunteers who took the time to fill out the questionnaire and return it for this study. I couldn't have completed this without each and every one of you. 


\section{TABLE OF CONTENTS}

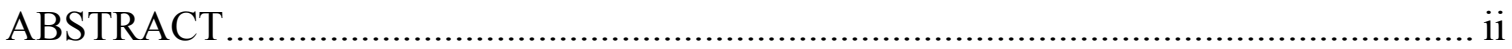

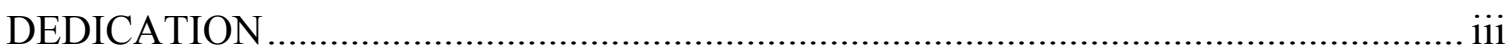

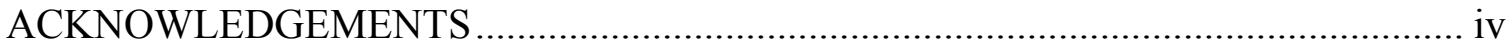

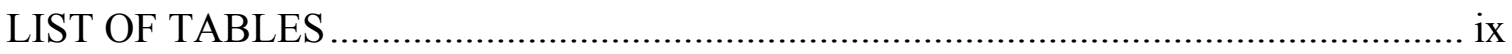

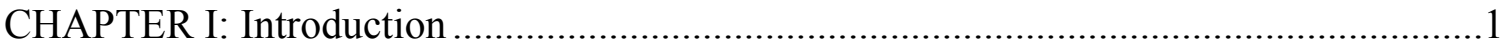

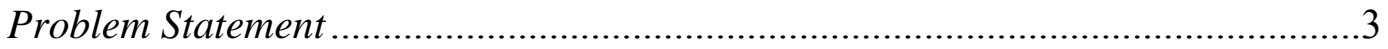

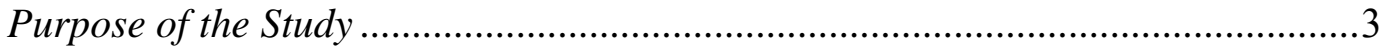

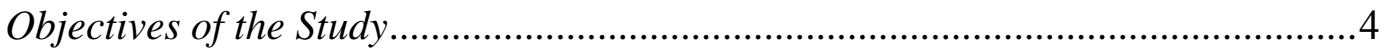

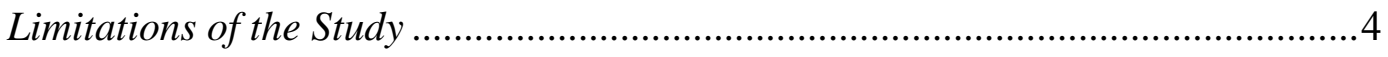

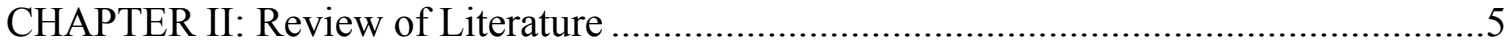

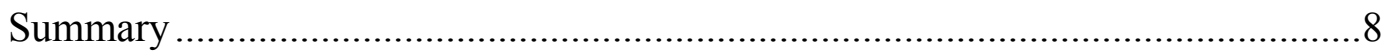

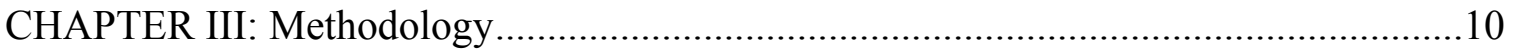

Purpose of the Study ...................................................................................... 10

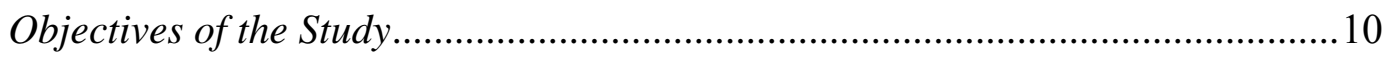

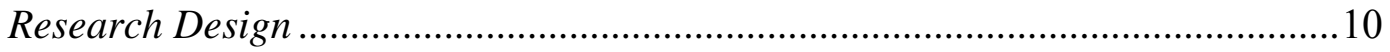

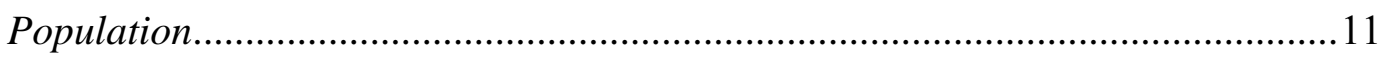

Target Population ......................................................................... 11

Accessible Population ....................................................................... 11

Sample Population ........................................................................... 11

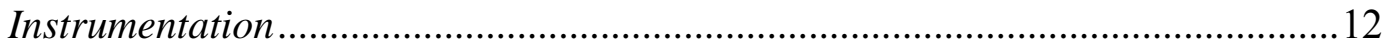

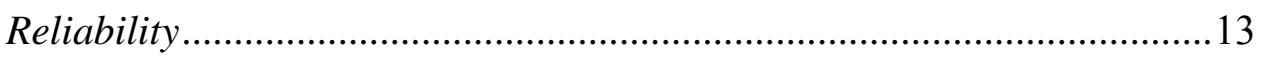

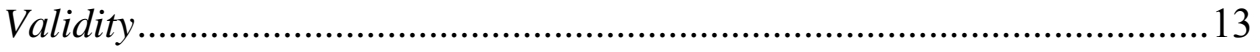




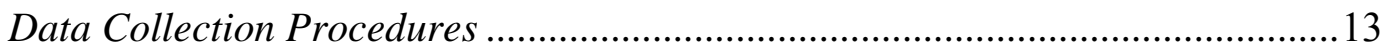

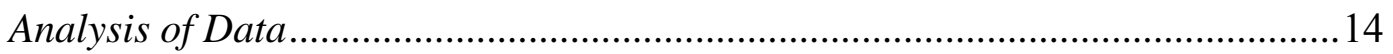

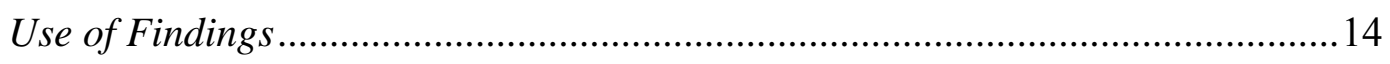

CHAPTER IV: Findings …………………………………......................................15

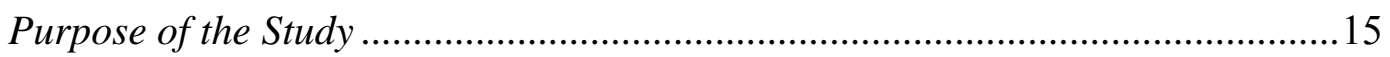

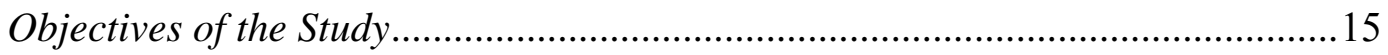

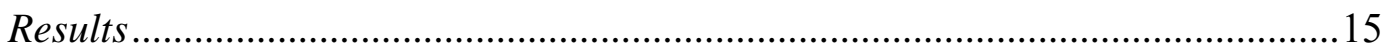

Reasons for Becoming a 4-H Volunteer......................................................16

Attitudes toward 4-H Volunteer Training ..................................................22

4-H Volunteer Training Participation and Needs .......................................31

Prior Training on Club Mechanics...............................................

Prior Training on Leadership Roles................................................32

Prior Training on Public Relations .................................................33

Prior Training on Volunteer Leader Training................................34

Prior Training on Subject Matter Topics...........................................35

Prior Training on Leisure Education ...............................................36

Prior Training on Skills 4-H Youth Learn .......................................37

Want Training on Club Mechanics ...............................................38

Want Training on Leadership Roles ..............................................40

Want Training on Public Relations..................................................41

Want Training on Volunteer Leader Training .................................42

Want Training on Subject Matter Topics.........................................43

Want Training on Leisure Education...............................................44 
Want Training on Skills 4-H Youth Learn

Method or Delivery Technique Desired for Training .................................46

Ranked Training Method or Delivery Technique .......................................47

Frequency of Participation in Training Activities .......................................53

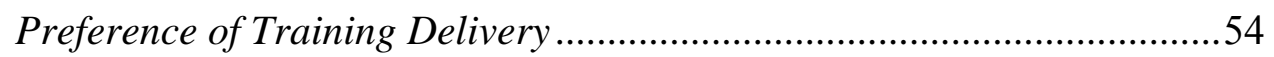

Most Important Thing Learned at a Volunteer Training Session ................56

Areas Volunteer Training Should Address More.........................................57

Demographic Characteristics...........................................................58

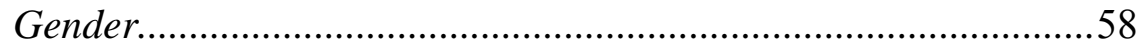

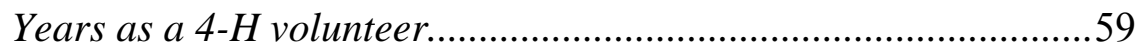

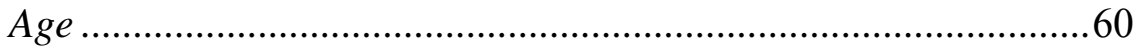

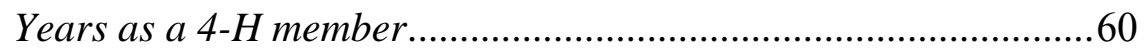

Training Sessions During the Past Twelve Months ........................61

Average Hours Volunteered To 4-H During A Month....................62

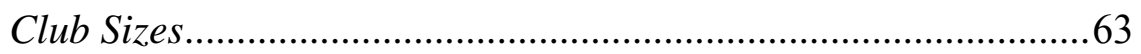

CHAPTER V: Summary, Conclusions, and Recommendations ........................................64

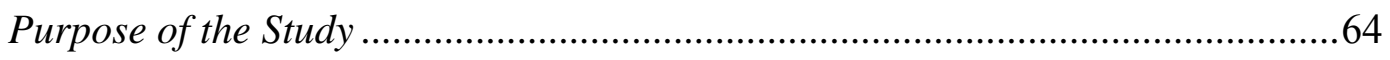

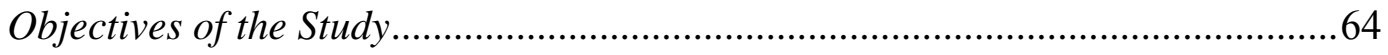

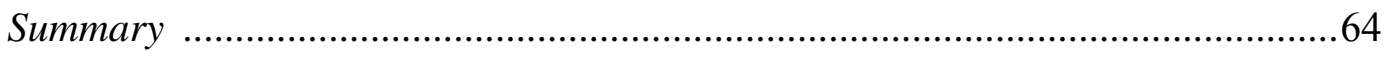

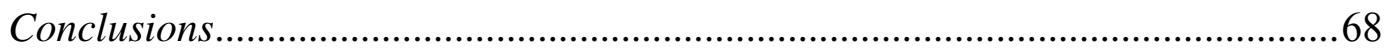

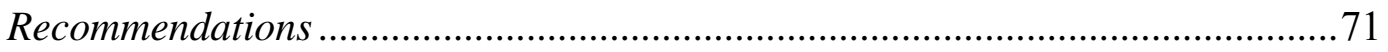

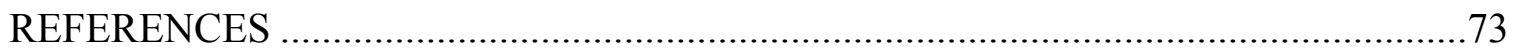

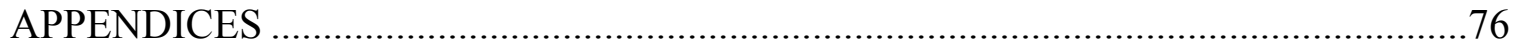


APPENDIX A: Cover Letter for Initial Mailing.

APPENDIX B: Data Collection Instrument

APPENDIX C: Cover Letter for Second Mailing...

APPENDIX D: Follow-up Postcard

APPENDIX E: Important Things Learned at Volunteer Training Session

APPENDIX F: Areas Volunteer Training Should Address More 100

VITA 105 
Table Title

\section{LIST OF TABLES}

1 Reasons 4-H Club Leaders Become a 4-H Volunteer......................................23

2 4-H Club Leaders’ Attitudes toward 4-H Volunteer Training............................28

3 4-H Club Leaders Prior Training on Club Mechanics......................................32

4 4-H Club Leaders Prior Training on Leadership Roles ..................................33

$5 \quad$ 4-H Club Leaders Prior Training on Public Relations ....................................34

6 4-H Club Leaders Prior Training on Volunteer Leader Training......................35

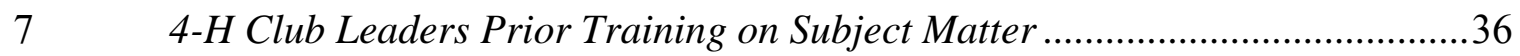

8 4-H Club Leaders Prior Training on Leisure Education...................................37

9 4-H Club Leaders Prior Training on Skills 4-H Youth Learn .............................39

10 4-H Club Leaders’ Desires for Training on Club Mechanics Topics.................40

11 4-H Club Leaders’ Desires for Training on Leadership Roles Topics...............41

12 4-H Club Leaders’ Desires for Training on Public Relations Topics .................42

13 4-H Club Leaders’ Desires for Training on Volunteer Reader Training

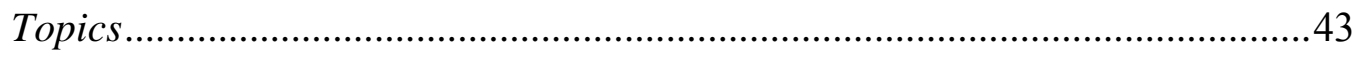

14 4-H Club Leaders’ Desires for Training on Subject Matter Topics ...................44

15 4-H Club Leaders’ Desires for Training on Leisure Education Topics .............45

16 4-H Club Leaders’ Desires for Training on Skills 4-H Youth Learn Topics ......46

17 4-H Club Leaders’ Preferences for Training Methods or Delivery

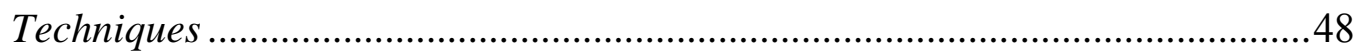

18 4-H Club Leaders’ Rankings of Training Methods or Delivery Techniques ......52

19 4-H Club Leaders Preference for Trainers....................................................54

20 4-H Club Leaders’ Preference of Timing for Training Delivery........................55 
21 Most Important Things Learned by 4-H Club Leaders at a Volunteer

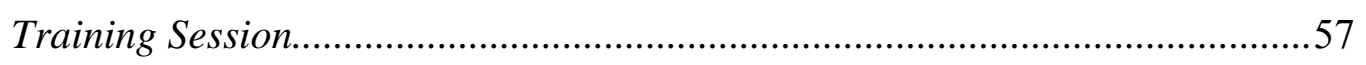

22 4-H Club Leaders' Perceptions of Areas Volunteer Training Should

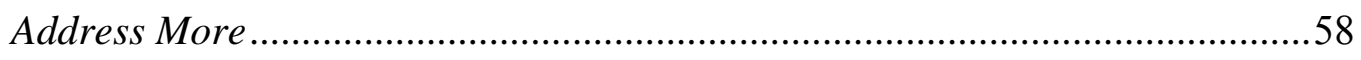

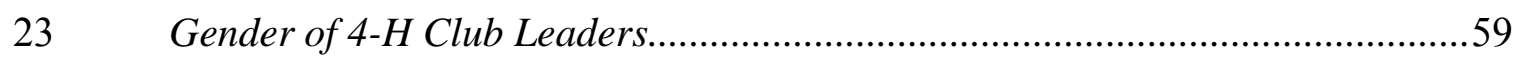

$24 \quad$ Number of Years 4-H Club Leaders have Served as a 4-H Volunteer.................59

$25 \quad$ Age of 4-H Club Leaders ……………………................................................60

$26 \quad$ Number of Years 4-H Club Leaders were a 4-H member..................................61

27 Number of Training Sessions Attended by 4-H Club Leaders During the

Past Twelve Month.........................................................................................62

28 Average Number of Hours per Month Volunteered by 4-H Club Leaders .........63

29 Average Club Size Reported by 4-H Club Leaders............................................63 


\section{CHAPTER I}

Introduction

Over 6.5 million youth participate in 4-H activities in all 50 states, U.S. territories, and military installations (National 4-H Council, 2007). This is more than any other leading youth organizations like the Boys \& Girls Club of America, Boy Scouts of America, Girl Scouts USA, FFA, and Big Brothers Big Sisters (National 4-H Council, 2007). It reaches youth from kindergarten through post-high school. 4-H has come a long way in just over 100 years from its origin as rural youth programs used to teach new agriculture technology to the adults (National 4-H Headquarters, 2006). Now 34\% of youth involved in $4-\mathrm{H}$ live in areas of over 50,000 people and only $11 \%$ of $4-\mathrm{H}$ youth live on farms (National 4-H Council, 2007).

By participating in the 4-H program, youth gain knowledge in three primary program areas: science, engineering, and technology; healthy living; and citizenship (National 4-H Council, 2007). 4-H members have the option to choose to complete over 1,000 projects on a variety of topics (National 4-H Council, 2007). The clubs that 4-H members are involved with may focus on one subject matter topic such as horses, shooting sports, or teen leadership. However, clubs can do whatever the members are interested in and clubs generally incorporate community service into their programming. Along the way, 4-H members learn many life skills as well as leadership and citizenship skills (National 4-H Council, 2007).

Many of the skills learned in 4-H can be incorporated into everyday life, providing 4-H members skills to succeed as adults in society. Cathann A. Kress, Director, Youth Development, Cooperative State Research, Education, and Extension Service 
(CSREES), United States Department of Agriculture (USDA), compiled research that showed 4-H participation does have an impact in youth's lives (2002) "A strong majority of club members felt they had gained skills that would support them throughout their lives" (Cress, 2002, p. 1). Areas that youth reported gaining experience in were goal setting, public speaking, problem solving, leadership skills, self-confidence, expanded horizons, citizenship, communication skills, planning skills, academic gains, organizational skills, patience, respect for (and from) others, tolerance, and "real-world" experience from hands-on projects (Cress, 2002, p.1). Compared to non 4-H youth, 4-H members rate their development of leadership skills higher in working with groups, understanding self, communicating, making decisions, and leadership (Boyd, Herring, \& Briers, 1992).

Educators at 106 land-grant universities help run the 4-H program with support from about 538,000 volunteers (National 4-H Council, 2007). These volunteers serve in various roles such as club leaders, project leaders, and activity leaders. When asked, volunteers feel that there were certain competencies that volunteer should have. In a study by Nester et al., (2006), volunteers in the state of West Virginia identified the top five volunteer competencies as interpersonal skills; communication; teaching/training skills; organizational; and managerial in that order. These are all skills that county agents and specialists can provide to the volunteers through training sessions.

In order to provide consistent quality services for youth, 4-H leaders must receive training. In a study of new 4-H volunteer leaders in the state of Oregon, volunteers rated several items that were deemed necessary to be a 4-H volunteer (VanWinkle, Busler, Bowman, \& Manoogian, 2002). They rated these items before and after receiving 
training on a scale from one to five with five being the highest. Their knowledge of 4-H increased to 4.37 after training from 3.12 before training (VanWinkle et al., 2002). Their preparedness to be a 4-H leader increased to 4.21 after training from 2.77 before training (VanWinkle et al., 2002). Other items such as planning and conducting club meetings; techniques for teaching 4-H members; and planning yearly 4-H programs were rated low before training $(0.97,0.96$, and 0.89 , respectively) (VanWinkle et al., 2002). After training, these same topics were rated 3.96, 3.88, and 3.97, respectively (VanWinkle et al. 2002).

Problem Statement

In the West Virginia 4-H program, county extension agents oversee numerous volunteers in a variety of roles. One of the main roles of volunteers in the 4- $\mathrm{H}$ program is serving as club leaders. To ensure that the objectives of the 4-H program are met, county extension agents need to have a well trained group of volunteers to serve in this capacity. In order to provide quality training it is important that county extension agents know how volunteers feel about their current training methods. They must also be able to identify topics that volunteers want included in future training sessions.

Purpose of the Study

The purpose of this study was to determine why individuals volunteer to be a 4-H leader, the attitudes volunteers have towards the different types of training they are offered in their individual county and across the state of West Virginia, the training needs of 4-H volunteers, and the methods by which 4-H volunteers prefer to receive training. 


\section{Objectives of the Study}

The following objectives for the study were to identify:

1. The reasons volunteers give their time to the 4-H program;

2. The attitudes $4-\mathrm{H}$ volunteers have toward $4-\mathrm{H}$ volunteer training activities;

3. The types of 4-H volunteer training opportunities that are available to volunteers;

4. The topics in which 4-H volunteers have received training and what topics they want to receive additional training;

5. The amount of training that each $4-\mathrm{H}$ volunteer has participated in and the amount of training in which each volunteer is willing to participate; and

6. The preferred methods of receiving 4-H volunteer training in 4-H.

\section{Limitations of the Study}

While there are many different roles volunteers may have in the 4-H program, this study focused primarily on volunteer club leaders. This study can only be applied to the 27 counties in the state of West Virginia in which the respondents reside. 


\section{CHAPTER II}

\section{Review of Literature}

Behind the 4-H program are multitudes of 4-H volunteers. The extension agents rely on volunteer leaders to provide $4-\mathrm{H}$ programming to community youth. "The considerable amount of literature on 4-H volunteers clearly indicates that the central and important role of these volunteers in the organization cannot be overemphasized" (Kwarteng, Smith, \& Miller, 1987, p. 55). Kwarteng et al. (1987) studied the attitudes 4-H agents and volunteers had toward six areas of volunteer leadership development; recruiting, training, motivation, recognition, retention, and supervision. They found that both the agents and the volunteers felt that all six areas were important to the development of 4-H volunteer leaders. Out of the six areas, the most important was considered to be training.

4- $\mathrm{H}$ volunteer training is necessary at any level of service to the 4- $\mathrm{H}$ program. Cook, Kiernan, and Ott (1986) found that despite the varied levels of experience and years of service, 4-H volunteers still want training in the areas of club mechanics, leadership roles, public relations, program development, awards and recognition, events/opportunities for members, and leisure education. Lowry (1986) found that leaders not only want more training, but also need more training. Although volunteers reported a lack of training, 4-H volunteers are willing to incorporate educational activities in their clubs (Lowry, 1986).

4-H volunteers participate in different types of training, but not frequently. Lowry's study (1986) revealed that "the vast majority of 4-H leaders have attended two or less state leaders' conferences and that $42.4 \%$ of the volunteer $4-\mathrm{H}$ leaders had not 
attended a county leader training activity supports the need for volunteer 4-H leader training” (p. 32). The method of training that volunteers identified as helpful varies based on the different aspects of leadership that Cook et al. studied (1986). County meeting; one on one with county staff; handbook; multicounty meeting; one on one with another leader; and newsletter were all training methods that volunteers stated as acceptable methods of training. No one method emerged as a favorite method of training.

4-H volunteer training is especially needed for new 4-H volunteers. VanWinkle et al. (2002) found that new volunteers who received training increased their knowledge and developed skills. The knowledge and skills acquired include increased knowledge and awareness, preparation for 4-H leader responsibilities, teaching techniques, club management, and age-appropriate activities. Kwarteng et al. (1987) found that any information that is significant to the 4-H program should be included in volunteer training so that volunteers can understand the importance of their responsibilities in regards to carrying out the values and mission of the $4-\mathrm{H}$ program.

There is a high turnover rate of new volunteers and one factor that may lead to this problem is a lack of continual training. Smith and Bigler (1985) found that $29 \%$ of the volunteers who were deemed "continuing" participated in various types of recurrent training, while only $19 \%$ of the volunteers who were deemed "discontinuing" participated. However there was no significant difference between the two groups when comparing attendance to an orientation program for 4-H Club leaders before and during their first year as a 4-H Club leader.

Another reason for turnover might be a lack of motivation. Providing recognition, both casual (verbal praise and encouragement) and formal (pins or certificates), can foster 
the retention of volunteer leaders (Kwarteng et al., 1987). However extension agents must understand that all volunteers are different and have different motivations for being a 4-H volunteer (Henderson, 1980). They also need to remember that volunteers' motivations are always changing and the best way to retain volunteers is to utilize them in a capacity where the volunteers can reap the benefits that they desire to receive from giving their time and talents (Henderson, 1980). "4-H Youth Development professionals should consider the most opportune ways to direct volunteer programs in order to maximize volunteer contributions to the organization" (Culp, McKee, \& Nestor, 2005, p. $1)$.

Volunteers also need a support system to help them become effective leaders. Kwarteng et al. (1987) suggests that supervision from the extension agent should occur throughout all stages of their outlined process; recruiting, training, motivation, recognition, retention, and supervision. This supervision comes in the form of visits, newsletters, bulletins, meetings, and constructive criticism (Kwarteng et al., 1987). However, Culp et al. (2005) found that many of today's county extension agents are younger than the volunteers and suggest that they may feel uncomfortable supervising and instructing them due to cultural beliefs in respect to elders.

Overall, 4-H volunteers seem to have certain characteristics in common. Boggs (1987) found that there are eight major characteristics that differentiate successful volunteer 4-H club leaders from others. These characteristics are: accepts all kinds of youth; is flexible; is enthusiastic; follows through on ideas and responsibilities; is open and honest; relates well to youth and adults; has ability to motivate people; and has a desire to help young people be productive members of the community. Many of these 
characteristics double as reasons volunteers give for volunteering. Henderson (1980) found that adults volunteer with 4-H because they like being associated with youth, like helping people, and want to have an influence on how people learn and grow. Many people who volunteer for 4-H have volunteered before for another organization or have volunteered during their youth (Culp, 1996).

The face of 4-H volunteers has shifted over time. In 1994, the "typical" Indiana 4-H volunteer was a female in her early 40 s and a professional, service worker, or homemaker with an average education of 13.93 years (Culp, 1996). Nestor et al. (2006) found that 4-H volunteers are more highly educated than previous studies showed with $68.22 \%$ of the respondents having earned a degree or post-high school certification. The study recommends taking advantage of this group of educated individuals by utilizing their talents, skills, and expertise in higher level volunteer roles. Over $30 \%$ of these highly educated volunteers hold a degree in education. Since these individuals already know strategies for teaching and understand different learning styles, volunteer training should focus on providing technical, subject-matter focused information.

\section{Summary}

Volunteers, whether young or old, new or experienced, all play a role in educating the youth enrolled in 4-H. No matter what the background of the volunteer may be, all volunteers can benefit from some form of training. While some people are born with certain skills that allow them naturally to be good leaders, others can learn the skills to let them succeed as a volunteer. It is in the best interest of county extension agents and extension specialists to learn what motivates their volunteers. By positively motivating them, the agents and specialists will see more retention of volunteers. County extension 
agents and extension specialists need to tap into their volunteers' talents and skills.

Volunteers hold a wealth of knowledge and can enhance the 4-H program. 


\section{Chapter III \\ Methodology}

Purpose of the Study

The purpose of this study was to determine why individuals volunteer to be a 4-H leader, the attitudes volunteers have towards the different types of training they are offered in their individual county and across the state of West Virginia, the training needs of 4-H volunteers, and the methods by which 4-H volunteers prefer to receive training. Objectives of the Study

The following objectives for the study were to identify:

1. The reasons volunteers give their time to the 4-H program;

2. The attitudes $4-\mathrm{H}$ volunteers have toward $4-\mathrm{H}$ volunteer training activities;

3. The types of 4-H volunteer training opportunities that are available to volunteers;

4. The topics in which $4-\mathrm{H}$ volunteers have received training and what topics they want to receive additional training;

5. The amount of training that each $4-\mathrm{H}$ volunteer has participated in and the amount of training in which each volunteer is willing to participate; and

6. The preferred methods of receiving 4-H volunteer training in 4-H.

\section{Research Design}

This study used a descriptive research design in the form of survey questionnaire to collect data. Descriptive research was used due to the confidentiality that it can guarantee, the large number of subjects that can be contacted, and the lack of interviewer bias (Ary, Jacobs, \& Razavieh, 2002). 


\section{Population}

Target Population. The target population for this study was all 4-H volunteers in the state of West Virginia. This includes club volunteers, activity volunteers, and project volunteers.

Accessible Population. West Virginia University Extension Service does not maintain a list of 4-H leaders in the state of West Virginia in their central office. In order to access the target population, the researchers contacted the agents responsible for 4-H programming in each of the 55 West Virginia counties and requested they provide a list of names and addresses for ten volunteers from their county. It was at the agent's discretion as to whether they felt comfortable releasing this information due to confidentiality of the leaders. The accessible population was $2874-\mathrm{H}$ volunteers from 27 counties in West Virginia.

Sample Population. Financial constraints limited the sample size to approximately 260 individuals randomly selected from the accessible population. The sample size was consistent with the recommendation of Krejcie and Morgan (1970).

There are several types of error that must be considered during the study: sample, frame, selection, and measurement. To eliminate sample errors, the study used simple random sampling in which each member of the accessible population had equal chance of being selected through the SPSS procedure. The Table for Determining Sample Size from a Given Population by Krejcie and Morgan (1970) was used to set the sample size needed for the study based on the accessible population. To eliminate frame errors and selection errors, the lists of the population were checked for accuracy and to make sure 
there were no duplications. To eliminate measurement error, the instrument was checked for validity and reliability through statistical tests and reviewed by a panel of experts.

\section{Instrumentation}

A questionnaire was sent to the sample population that included Likert scale questions, open ended questions, multiple response questions, and demographic questions. This questionnaire consisted of one hundred twenty two questions. Parts of this questionnaire were derived from studies completed by Cook, Kiernan, and Ott (1986), Henderson (1980), Lowry (1987), and Boggs (1986). Also information about volunteers with West Virginia's 4-H program fwas utilized.

The questionnaire was formatting using suggestions from Ary et al. (2005). The contents were arranged in an attractive manner and the questions were composed so they were easily comprehendible by the subject and convenient for coding by the researcher. Demographic questions were placed at the end of the instrument, and the most important questions were included at the beginning of the survey.

Using a Likert scale, the first part of the questionnaire established the respondents' reasons for becoming a 4-H volunteer. Part two of the questionnaire also used Likert items to determine the respondents' attitudes toward 4-H volunteer training. Part three was broken into two sections. First, the respondents were to indicate which topics they have already received training in by circling yes or no. Then the respondents were to indicate which topics they wished to receive more training on by circling yes or no. Part four asked respondents to determine what types of delivery methods they preferred by circling yes or no. Out of their preferred methods, respondents were to rank them in order from 1 to 5 with 1 standing for the best method of delivery. 
Part five requested additional information about 4-H training activities. Information was collected about preferred training frequency and preferred training personnel. Respondents also identified the most important thing they have learned at a volunteer training session and what area(s) they wish volunteer training addressed more. Part six consisted of demographic questions. Respondents answered questions about gender, years as a 4-H volunteer, age, years as a $4-\mathrm{H}$ member, number of training sessions attended during the past 12 months, average hours volunteered to $4-\mathrm{H}$ in a month, number of 4-H members in their clubs, and number of other volunteer leaders involved with their club.

Reliability. Reliability of the instrument was established by using the final data set from all respondents. The Spearman-Brown split half statistic was used due to primarily nominal and ordinal scale data. The reliability of the instrument was found to be extensive at .7883 (Robinson, Shaver, \& Wrightsman, 1991). The instrument was established as a reliable measure.

Validity. The content validity and face validity of the research instrument was established by a panel of experts. This panel was comprised of West Virginia University professors and extension specialists who had direct knowledge of the types of training currently being offered to $4-\mathrm{H}$ volunteers. The panel of experts concluded the instrument had content and face validity.

\section{Data Collection Procedures}

The Dillman (2000) total design method was used for this study. The first mailing for the study included the cover letter, instrument, and a self-addressed stamped envelope. After the deadline stated in the cover letter passed, a second mailing of the 
packet followed, containing the same three elements. After the second deadline expired, the non-respondents were contacted by a postcard. Still there were a number of nonrespondents. To determine if non-response error existed, the late respondents, those who completed the survey after the first deadline, were compared to the early respondents on gender, years as a 4- $\mathrm{H}$ volunteer, age, and years as a 4- $\mathrm{H}$ member. Of the 144 returned surveys, 75 were returned by the original deadline and 69 were deemed late respondents. Chi-square statistical procedures were not significant $(\alpha \leq .05)$ for gender $(\chi=.327)$; years as a $4-\mathrm{H}$ volunteer $(\chi=.216)$; age $(\chi=.090)$; and years as a 4-H member $(\chi=.598)$. There were no difference between early and late respondents and generalizations could be made to the entire population.

\section{Analysis of Data}

The data collected from each respondent were compiled into an Excel spreadsheet and were analyzed using the SPSS data analysis software. Descriptive analyses were performed on the data, and the appropriate methods of reporting central tendency and variability for each type of data were used.

\section{Use of Findings}

The findings from this study will be used to draw conclusions about the perceptions volunteer leaders have toward volunteer training. The information gathered will be shared with county 4-H extension agents, extension specialists, and 4- $\mathrm{H}$ administrators in hopes that it will be used to enhance training opportunities available to volunteers. 


\section{CHAPTER IV}

\section{Findings}

\section{Purpose of the Study}

The purpose of this study was to determine why individuals volunteer to be a 4-H leader, the attitudes volunteers have towards the different types of training they are offered in their individual county and across the state of West Virginia, the training needs of 4-H volunteers, and the methods by which 4-H volunteers prefer to receive training.

\section{Objectives of the Study}

The following objectives for the study were to identify:

1. The reasons volunteers give their time to the 4-H program;

2. The attitudes $4-\mathrm{H}$ volunteers have toward $4-\mathrm{H}$ volunteer training activities;

3. The types of 4-H volunteer training opportunities that are available to volunteers;

4. The topics in which $4-\mathrm{H}$ volunteers have received training and what topics they want to receive additional training;

5. The amount of training that each $4-\mathrm{H}$ volunteer has participated in and the amount of training in which each volunteer is willing to participate; and

6. The preferred methods of receiving 4-H volunteer training in 4-H.

\section{Results}

Of the 260 sent questionnaires, there were a total of 144 returned. Seventy-five of the returned questionnaires were deemed early respondents and 69 returned questionnaires were late respondents. The response rate was $55.3 \%$. 


\section{Reasons for Becoming a 4-H Volunteer}

The first part of the questionnaire consisted of Likert scale items with six possible answers ranging from strongly disagree to strongly agree. The items were used to measure the reasons individuals become a 4-H volunteer. Fifteen respondents (11.5\%) reported that they strongly disagreed with the statement "I am a 4-H volunteer because I want to be with my child(ren) in the 4-H program" (see Table 1). Four respondents (3.1\%) moderately disagreed with that statement while three respondents $(2.3 \%)$ slightly disagreed. Nine respondents $(6.9 \%)$ reported that they slightly agreed with the statement and nineteen respondents (14.5\%) moderately agreed. Eighty-one respondents $(61.8 \%)$ strongly agreed with the statement "I am a 4-H volunteer because I want to be with my child(ren) in the 4-H program."

One hundred eighteen respondents strongly agreed with the statement, "I am a 4$\mathrm{H}$ volunteer because I like helping people" (see Table 1). Twenty respondents (14.2\%) moderately agreed with the statement and three respondents (2.1\%) slightly agreed with the statement. One hundred sixteen respondents $(82.3 \%)$ reported that they strongly agreed with the statement, "I am a 4-H volunteer because I like associating with youth" (see Table 1). Twenty-one respondents (14.9\%) moderately agreed with the statement and four respondents $(2.8 \%)$ slightly agreed with the statement.

In response to the statement, "I am a 4-H volunteer because I want to have an influence on how young people learn and grow," 112 respondents (79.4\%) strongly agreed with the comment (see Table 1). Twenty-three respondents $(16.3 \%)$ moderately agreed and six respondents (4.3\%) slightly agreed with the statement. 
Ninety-six respondents (68.1\%) strongly agreed with the statement, "I volunteer in 4-H because it is a way to improve my community" (see Table 1). Thirty-five respondents (24.8\%) moderately agreed, nine respondents (6.4\%) slightly agreed, and one respondent $(0.7 \%)$ slightly disagreed with the statement.

Eighty-four respondents (60.0\%) strongly agreed with the statement, "I am a 4-H volunteer because it is a way I can express my caring and concern for others" (see Table 1). Forty respondents (28.6\%) moderately agreed, 13 respondents $(9.3 \%)$ slightly agreed, and three respondents $(2.1 \%)$ slightly disagreed with this statement.

Forty-six respondents (33.1\%) strongly agreed with the statement, "Volunteering in 4-H gives me a chance to meet other volunteers" (see Table 1). Forty-four respondents (31.7\%) moderately agreed and 39 respondents (28.1\%) slightly agreed, while nine respondents $(6.5 \%)$ slightly disagreed. One respondent $(0.7 \%)$ strongly disagreed with the statement.

"I am a 4-H volunteer because I want to learn new things" was a statement that 51 respondents (37.0\%) expressed strong agreement (see Table 1). Fifty respondents (36.2\%) moderately agreed, 28 respondents $(20.3 \%)$ slightly agreed, seven respondents (5.1\%) slightly disagreed, one respondent $(0.7 \%)$ moderately disagreed, and one respondent $(0.7 \%)$ strongly disagreed with the statement.

"As a 4-H volunteer, I prefer to work with groups of people rather than alone," had 44 respondents (31.7\%) who strongly agreed, 44 respondents (31.7\%) who moderately agreed, and 36 respondents $(25.9 \%)$ who slightly agreed with the statement (see Table 1). Thirteen respondents (9.4\%) slightly disagreed and two respondents (1.4\%) strongly disagreed with the statement. 
Fifty-eight respondents (41.4\%) strongly agreed with the statement, "I am a 4-H volunteer because I want to teach and lead others" (see Table 1). Forty-nine respondents (35.0\%) moderately agreed, and 23 respondents (16.4\%) slightly agreed with the statement. Eight respondents (5.7\%) slightly disagreed, one respondent $(0.7 \%)$ moderately disagreed, and one respondent $(0.7 \%)$ strongly disagreed with the statement.

Seventy one respondents (51.5\%) strongly agreed with the statement, "I like being involved in the leadership of the 4-H program" (see Table 1). Forty-one respondents (29.5\%) moderately agreed and 23 respondents (16.5\%) slightly agreed, while four respondents $(2.9 \%)$ slightly disagreed with the statement.

For the statement, "I am a 4-H volunteer because I like the challenge of the task," $40.0 \%$ of the respondents $(N=56)$ strongly agreed, $28.6 \%$ of the respondents $(N=40)$ moderately agreed, and $20.7 \%$ of the respondents $(N=29)$ slightly agreed with the statement (see Table 1). Eleven respondents (7.9\%) slightly disagreed, $1.4 \%$ of the respondents $(N=2)$ moderately disagreed, and $1.4 \%$ of the respondents $(N=2)$ strongly disagreed with this statement.

Fifty-three respondents (38.1\%) strongly agreed with the statement, "I am a 4-H volunteer because I feel needed in the program" (see Table 1). Forty-four respondents (31.7\%) moderately agreed, 30 respondents $(21.6 \%)$ slightly agreed, 10 respondents (7.2\%) slightly disagreed, one respondent ( $0.7 \%)$ moderately disagreed, and one respondent $(0.7 \%)$ strongly disagreed with the statement.

Twenty-five respondents (18.0\%) strongly agreed with the statement, "As a 4-H volunteer, it is important to me that people like me" (see Table 1). Forty-four respondents $(31.7 \%)$ moderately agreed with the statement and 51 respondents $(36.7 \%)$ slightly 
agreed with the statement. Nine respondents (6.5\%) slightly disagreed, six respondents (4.3\%) moderately disagreed, and four respondents $(2.9 \%)$ strongly disagreed with the statement.

Fifty-two respondents $(37.4 \%)$ reported that they strongly agreed with the statement, “As a 4-H volunteer, I have goals for what I want to accomplish as a volunteer" (see Table 1). Fifty-three respondents (38.1\%) moderately agreed, 28 respondents (20.1\%) slightly agreed, five respondents $(3.6 \%)$ slightly disagreed, and one respondent $(0.7 \%)$ moderately disagreed with the statement.

"I am a 4-H volunteer because it is a constructive use of my leisure time." was a statement that 44 respondents (31.4\%) expressed strong agreement (see Table 1). Fortytwo respondents $(37.1 \%)$ moderately agreed and 28 respondents $(20.0 \%)$ slightly agreed with the statement. Fifteen respondents (10.7\%) slightly disagreed, six respondents (4.3\%) moderately disagreed, and five respondents (3.6\%) strongly disagreed with the statement. Several respondents wrote the comment, "what leisure time!" in the margins of the survey.

Fifty-four respondents (38.6\%) strongly agreed with the statement, "As a volunteer, I like to receive feedback from Extension staff, parents, and 4-H members about how I am doing" (see Table 1). Fifty-two respondents (37.1\%) moderately agreed, 28 respondents $(20.0 \%)$ slightly agreed, two respondents $(1.4 \%)$ slightly disagreed, one respondent $(0.7 \%)$ moderately disagreed, and three respondents $(2.1 \%)$ strongly disagreed with the statement.

"I am a 4-H volunteer because I like to be involved in making decisions and program planning" had 40 respondents $(28.8 \%)$ that strongly agreed with the comment 
(see Table 1). Forty-three respondents (30.9\%) moderately agreed, 39 respondents (28.1\%) slightly agreed, 11 respondents (7.9\%) slightly disagreed, three respondents (2.2\%) moderately disagreed, and three respondents $(2.2 \%)$ strongly disagreed with the statement.

Fifty respondents (36.0\%) strongly agreed with the statement, "I am a 4-H volunteer because it is a task I can do well" (see Table 1). Fifty-one respondents (36.7\%) moderately agreed and thirty-two respondents (23.0\%) slightly agreed, while four respondents (2.9\%) slightly disagreed and two respondents (1.4\%) strongly disagreed with the statement.

The statement, "As a 4-H volunteer, I enjoy being able to "do my own thing" had 21 respondents (15.4\%) expressing strong agreement with the comment (see Table 1). Thirty-seven respondents (27.2\%) moderately agreed and 31 respondents $(22.8 \%)$ slightly agreed, while 30 respondents (22.1\%) slightly disagreed, four respondents $(2.9 \%)$ moderately disagreed, and 13 respondents (9.6\%) strongly disagreed with the statement.

Fifty respondents (36.0\%) strongly agreed with the statement, "I am a 4-H volunteer because I feel an obligation to 4-H because of what it had done for me" (see Table 1$)$. Twenty-four respondents $(17.3 \%)$ moderately agreed, 37 respondents $(26.6 \%)$ slightly agreed, 14 respondents (10.1\%) slightly disagreed, four respondents (2.9\%) moderately disagreed, and 10 respondents (7.2\%) strongly disagreed with the statement.

For the statement, "I volunteer in 4-H because I like to be responsible for 4- $\mathrm{H}$ programs," twenty-six respondents (18.7\%) of the respondents strongly agreed with the comment (see Table 1). Thirty-one respondents (22.3\%) of the respondents moderately agreed with the statement, $33.1 \%$ of the respondents $(N=46)$ slightly agreed with the 
statement, $11.5 \%$ of the respondents $(N=16)$ slightly disagreed with the statement, $5.8 \%$ of the respondents $(N=8)$ moderately disagreed with the statement, and $8.6 \%$ of the respondents $(N=12)$ strongly disagreed with the statement.

"I receive status in my community because I am a 4-H volunteer" had eight respondents (5.7\%) that strongly agreed with the comment (see Table 1). Fourteen respondents (10.0\%) moderately agreed, 52 respondents (37.1\%) slightly agreed, 23 respondents (16.4\%) slightly disagreed, 14 respondents (10.0\%) moderately disagreed, and 29 respondents (20.7\%) strongly disagreed with this statement.

Twelve respondents (8.6\%) strongly agreed with the statement, "I am a 4-H volunteer because I can’t say “no" when I am asked” (see Table 1). Nineteen respondents (13.6\%) moderately agreed, 34 respondents (24.3\%) slightly agreed, 26 respondents (18.6\%) slightly disagreed, 15 respondents (10.7\%) moderately disagreed, 34 respondents (24.3\%) strongly disagreed with the statement.

Only one respondent $(0.7 \%)$ strongly agreed with the statement, "I am a 4-H volunteer because I like to receive recognition for being a volunteer" (see Table 1). Seven respondents $(5.0 \%)$ moderately agreed, 30 respondents (21.6\%) slightly agreed, 37 respondents (26.6\%) slightly disagreed, 16 respondents (11.5\%) moderately disagreed, and 48 respondents (34.5\%) strongly disagreed with the statement.

"I am a 4-H volunteer because I want to have influence over others" was strongly agreed with by 15 respondents (11.2\%) (see Table 1). Twenty-one respondents (15.7\%) moderately agreed, 37 respondents (27.6\%) slightly agreed, 24 respondents (17.9\%) slightly disagreed, nine respondents (6.7\%) moderately disagreed, and 28 respondents $(20.9 \%)$ strongly disagreed with the statement. 
Three respondents (2.2\%) strongly agreed with the statement, "I am a 4-H volunteer in order to gain experience and skills which might lead to employment" (see Table 1$)$. Eleven respondents (8.0\%) moderately agreed, 19 respondents (13.8\%) slightly agreed, 29 respondents $(21.0 \%)$ slightly disagreed, 15 respondents $(10.9 \%)$ moderately disagreed, and 61 respondents $(44.2 \%)$ strongly disagreed with the statement.

\section{Attitudes toward 4-H Volunteer Training}

The respondents were asked twelve Likert scale questions to determine their attitudes toward 4-H volunteer training. The questions had six possible answers ranging from strongly disagree to strongly agree. Sixty-one respondents (43.9\%) strongly agreed with the comment, "Training is important to becoming a volunteer club leader" (see Table 2). Forty-nine respondents (35.3\%) moderately agreed, twenty-one respondents (15.1\%) slightly agreed, three respondents (2.2\%) slightly disagreed, two respondents $(1.4 \%)$ moderately disagreed, and three respondents $(2.2 \%)$ strongly disagreed with the statement.

Three respondents (2.2\%) strongly agreed with the statement, "Training is only for persons who have no 4-H background" (see Table 2). Twelve respondents $(8.7 \%)$ moderately agreed, 14 respondents (10.1\%) slightly agreed, 18 respondents $(13.0 \%)$ slightly disagreed, 19 respondents $(13.8 \%)$ moderately disagreed, and 72 respondents $(52.2 \%)$ strongly disagreed with the statement. 
Table 1

Reasons 4-H Club Leaders Become a 4-H Volunteer

\begin{tabular}{|c|c|c|c|c|c|c|c|c|c|c|c|c|}
\hline & \multicolumn{2}{|c|}{$\begin{array}{l}\text { Strongly } \\
\text { Disagree }\end{array}$} & \multicolumn{2}{|c|}{$\begin{array}{l}\text { Moderately } \\
\text { Disagree }\end{array}$} & \multicolumn{2}{|c|}{$\begin{array}{l}\text { Slightly } \\
\text { Disagree }\end{array}$} & \multicolumn{2}{|c|}{$\begin{array}{l}\text { Slightly } \\
\text { Agree }\end{array}$} & \multicolumn{2}{|c|}{$\begin{array}{c}\text { Moderately } \\
\text { Agree }\end{array}$} & \multicolumn{2}{|c|}{$\begin{array}{l}\text { Strongly } \\
\text { Agree }\end{array}$} \\
\hline & $N$ & $\%$ & $N$ & $\%$ & $N$ & $\%$ & $N$ & $\%$ & $N$ & $\%$ & $N$ & $\%$ \\
\hline $\begin{array}{l}\text { I am a } 4-\mathrm{H} \text { volunteer because I want to be with } \\
\text { my child(ren) in the } 4 \text {-H program }\end{array}$ & 15 & 11.5 & 4 & 3.1 & 3 & 2.3 & 9 & 6.9 & 19 & 14.5 & 81 & 61.8 \\
\hline $\begin{array}{l}\text { I am a 4-H volunteer because I like helping } \\
\text { people }\end{array}$ & 0 & .0 & 0 & .0 & 0 & .0 & 3 & 2.1 & 20 & 14.2 & 118 & 83.7 \\
\hline $\begin{array}{l}\text { I am a } 4-\mathrm{H} \text { volunteer because I like associating } \\
\text { with youth }\end{array}$ & 0 & .0 & 0 & .0 & 0 & .0 & 4 & 2.8 & 21 & 14.9 & 116 & 82.3 \\
\hline $\begin{array}{l}\text { I am a 4-H volunteer because I want to have } \\
\text { influence on how young people learn and grow }\end{array}$ & 0 & .0 & 0 & .0 & 0 & .0 & 6 & 4.3 & 23 & 16.3 & 112 & 79.4 \\
\hline $\begin{array}{l}\text { I volunteer in } 4-\mathrm{H} \text { because it is a way to } \\
\text { improve my community }\end{array}$ & 0 & .0 & 0 & .0 & 1 & .7 & 9 & 6.4 & 35 & 24.8 & 96 & 68.1 \\
\hline $\begin{array}{l}\text { I am a 4-H volunteer because it is a way I can } \\
\text { express my caring and concern for others }\end{array}$ & 0 & .0 & 0 & .0 & 3 & 2.1 & 13 & 9.3 & 40 & 28.6 & 84 & 60.0 \\
\hline $\begin{array}{l}\text { Volunteering in } 4 \text {-H gives me a chance to meet } \\
\text { other volunteers }\end{array}$ & 1 & .7 & 0 & .0 & 9 & 6.5 & 39 & 28.1 & 44 & 31.7 & 46 & 33.1 \\
\hline
\end{tabular}


Table 1 (Continued)

Reasons 4-H Club Leaders Become a 4-H Volunteer

\begin{tabular}{|c|c|c|c|c|c|c|c|c|c|c|c|c|}
\hline & \multicolumn{2}{|c|}{$\begin{array}{l}\text { Strongly } \\
\text { Disagree }\end{array}$} & \multicolumn{2}{|c|}{$\begin{array}{l}\text { Moderately } \\
\text { Disagree }\end{array}$} & \multicolumn{2}{|c|}{$\begin{array}{l}\text { Slightly } \\
\text { Disagree }\end{array}$} & \multicolumn{2}{|c|}{$\begin{array}{l}\text { Slightly } \\
\text { Agree }\end{array}$} & \multicolumn{2}{|c|}{$\begin{array}{l}\text { Moderately } \\
\text { Agree }\end{array}$} & \multicolumn{2}{|c|}{$\begin{array}{l}\text { Strongly } \\
\text { Agree }\end{array}$} \\
\hline & $N$ & $\%$ & $N$ & $\%$ & $N$ & $\%$ & $N$ & $\%$ & $N$ & $\%$ & $N$ & $\%$ \\
\hline $\begin{array}{l}\text { I am a 4-H volunteer because I want to learn } \\
\text { new things }\end{array}$ & 1 & .7 & 1 & .7 & 7 & 5.1 & 28 & 20.3 & 50 & 36.2 & 51 & 37.0 \\
\hline $\begin{array}{l}\text { As a } 4-\mathrm{H} \text { volunteer, I prefer to work with groups } \\
\text { of people rather than alone }\end{array}$ & 2 & 1.4 & 0 & .0 & 13 & 9.4 & 36 & 25.9 & 44 & 31.7 & 44 & 31.7 \\
\hline $\begin{array}{l}\text { I am a 4-H volunteer because I want to teach } \\
\text { and lead others }\end{array}$ & 1 & .7 & 1 & .7 & 8 & 5.7 & 23 & 16.4 & 49 & 35.0 & 58 & 41.4 \\
\hline $\begin{array}{l}\text { I like being involved in the leadership of the } 4 \text { - } \\
\text { H program }\end{array}$ & 0 & .0 & 0 & .0 & 4 & 2.9 & 23 & 16.5 & 41 & 29.5 & 71 & 51.1 \\
\hline $\begin{array}{l}\text { I am a } 4-\mathrm{H} \text { volunteer because I like the } \\
\text { challenge of the task }\end{array}$ & 2 & 1.4 & 2 & 1.4 & 11 & 7.9 & 29 & 20.7 & 40 & 28.6 & 56 & 40.0 \\
\hline $\begin{array}{l}\text { I am a } 4-\mathrm{H} \text { volunteer because I feel needed in } \\
\text { the program }\end{array}$ & 1 & .7 & 1 & .7 & 10 & 7.2 & 30 & 21.6 & 44 & 31.7 & 53 & 38.1 \\
\hline $\begin{array}{l}\text { As a } 4-\mathrm{H} \text { volunteer, it is important to me that } \\
\text { people like me }\end{array}$ & 4 & 2.9 & 6 & 4.3 & 9 & 6.5 & 51 & 36.7 & 44 & 31.7 & 25 & 18.0 \\
\hline
\end{tabular}


Table 1 (Continued)

Reasons 4-H Club Leaders Become a 4-H Volunteer

\begin{tabular}{|c|c|c|c|c|c|c|c|c|c|c|c|c|}
\hline & \multicolumn{2}{|c|}{$\begin{array}{l}\text { Strongly } \\
\text { Disagree }\end{array}$} & \multicolumn{2}{|c|}{$\begin{array}{l}\text { Moderately } \\
\text { Disagree }\end{array}$} & \multicolumn{2}{|c|}{$\begin{array}{l}\text { Slightly } \\
\text { Disagree }\end{array}$} & \multicolumn{2}{|c|}{$\begin{array}{l}\text { Slightly } \\
\text { Agree }\end{array}$} & \multicolumn{2}{|c|}{$\begin{array}{l}\text { Moderately } \\
\text { Agree }\end{array}$} & \multicolumn{2}{|c|}{$\begin{array}{l}\text { Strongly } \\
\text { Agree }\end{array}$} \\
\hline & $N$ & $\%$ & $N$ & $\%$ & $N$ & $\%$ & $N$ & $\%$ & $N$ & $\%$ & $N$ & $\%$ \\
\hline $\begin{array}{l}\text { As a 4-H volunteer, I have goals for what I want } \\
\text { to accomplish as a volunteer }\end{array}$ & 0 & .0 & 1 & .7 & 5 & 3.6 & 28 & 20.1 & 53 & 38.1 & 52 & 37.4 \\
\hline $\begin{array}{l}\text { I am a 4-H volunteer because it is a constructive } \\
\text { use of my leisure time }\end{array}$ & 5 & 3.6 & 6 & 4.3 & 15 & 10.7 & 28 & 20.0 & 42 & 30.0 & 44 & 31.4 \\
\hline $\begin{array}{l}\text { As a volunteer, I like to receive feedback from } \\
\text { Extension staff, parents, and } 4-\mathrm{H} \text { members } \\
\text { about how I am doing }\end{array}$ & 3 & 2.1 & 1 & .7 & 2 & 1.4 & 28 & 20.0 & 52 & 37.1 & 54 & 38.6 \\
\hline $\begin{array}{l}\text { I am a } 4-\mathrm{H} \text { volunteer because I like to be } \\
\text { involved in making decisions and program } \\
\text { planning }\end{array}$ & 3 & 2.2 & 3 & 2.2 & 11 & 7.9 & 39 & 28.1 & 43 & 30.9 & 40 & 28.8 \\
\hline $\begin{array}{l}\text { I am a 4-H volunteer because it is a task I can do } \\
\text { well }\end{array}$ & 2 & 1.4 & 0 & .0 & 4 & 2.9 & 32 & 23.0 & 51 & 36.7 & 50 & 36.0 \\
\hline $\begin{array}{l}\text { As a } 4-\mathrm{H} \text { volunteer, I enjoy being able to "do } \\
\text { my own thing" }\end{array}$ & 13 & 9.6 & 4 & 2.9 & 30 & 22.1 & 31 & 22.8 & 37 & 27.2 & 21 & 15.4 \\
\hline
\end{tabular}


Table 1 (Continued)

Reasons 4-H Club Leaders Become a 4-H Volunteer

\begin{tabular}{|c|c|c|c|c|c|c|c|c|c|c|c|c|}
\hline & \multicolumn{2}{|c|}{$\begin{array}{l}\text { Strongly } \\
\text { Disagree }\end{array}$} & \multicolumn{2}{|c|}{$\begin{array}{l}\text { Moderately } \\
\text { Disagree }\end{array}$} & \multicolumn{2}{|c|}{$\begin{array}{l}\text { Slightly } \\
\text { Disagree }\end{array}$} & \multicolumn{2}{|c|}{$\begin{array}{l}\text { Slightly } \\
\text { Agree }\end{array}$} & \multicolumn{2}{|c|}{$\begin{array}{l}\text { Moderately } \\
\text { Agree }\end{array}$} & \multicolumn{2}{|c|}{$\begin{array}{l}\text { Strongly } \\
\text { Agree }\end{array}$} \\
\hline & $N$ & $\%$ & $N$ & $\%$ & $N$ & $\%$ & $N$ & $\%$ & $N$ & $\%$ & $N$ & $\%$ \\
\hline $\begin{array}{l}\text { I am a 4-H volunteer because I feel an } \\
\text { obligation to 4-H because of what it has done } \\
\text { for me }\end{array}$ & 10 & 7.2 & 4 & 2.9 & 14 & 10.1 & 37 & 26.6 & 24 & 17.3 & 50 & 36.0 \\
\hline $\begin{array}{l}\text { I volunteer in } 4-\mathrm{H} \text { because I like to be } \\
\text { responsible for } 4-\mathrm{H} \text { programs }\end{array}$ & 12 & 8.6 & 8 & 5.8 & 16 & 11.5 & 46 & 33.1 & 31 & 22.3 & 26 & 18.7 \\
\hline $\begin{array}{l}\text { I receive status in my community because I am } \\
\text { a } 4-\mathrm{H} \text { volunteer }\end{array}$ & 29 & 20.7 & 14 & 10.0 & 23 & 16.4 & 52 & 37.1 & 14 & 10.0 & 8 & 5.7 \\
\hline $\begin{array}{l}\text { I am a 4-H volunteer because I can't say "no" } \\
\text { when I am asked }\end{array}$ & 34 & 24.3 & 15 & 10.7 & 26 & 18.6 & 34 & 24.3 & 19 & 13.6 & 12 & 8.6 \\
\hline $\begin{array}{l}\text { I am a 4-H volunteer because I like to receive } \\
\text { recognition for being a volunteer }\end{array}$ & 48 & 34.5 & 16 & 11.5 & 37 & 26.6 & 30 & 21.6 & 7 & 5.0 & 1 & .7 \\
\hline $\begin{array}{l}\text { I am a 4-H volunteer because I want to have } \\
\text { influence over others }\end{array}$ & 28 & 20.9 & 9 & 6.7 & 24 & 17.9 & 37 & 27.6 & 21 & 15.7 & 15 & 11.2 \\
\hline $\begin{array}{l}\text { I am a 4-H volunteer in order to gain experience } \\
\text { and skills which might lead to employment }\end{array}$ & 61 & 44.2 & 15 & 10.9 & 29 & 21.0 & 19 & 13.8 & 11 & 8.0 & 3 & 2.2 \\
\hline
\end{tabular}


Two respondents (1.5\%) strongly agreed with the statement "Training is only for new volunteers" (see Table 2). Four respondents (2.9\%) moderately agreed, $8.0 \%$ of the respondents $(N=11)$ slightly agreed, $14.6 \%$ of the respondents $(N=20)$ slightly disagreed, $18.2 \%$ of the respondents $(N=25)$ moderately disagreed, and $54.7 \%$ of the respondents $(N=75)$ strongly disagreed with the statement.

The statement, "The amount of training my county offers is adequate for learning how to be a club leader," had 19 respondents (13.8\%) strongly agree with the comment (see Table 2). Twenty-seven respondents (19.6\%) moderately agreed, 35 respondents (25.4\%) slightly agreed, 24 respondents (17.4\%) slightly disagreed, 20 respondents (14.5\%) moderately disagreed, and 13 respondents (9.4\%) strongly disagreed with the statement.

Five respondents (3.6\%) strongly agreed with the statement, "Yearly volunteer training sessions would not be beneficial to club leaders" (see Table 2). Seven respondents (5.0\%) moderately agreed, five respondents (3.6\%) slightly agreed, 27 respondents (19.4\%) slightly disagreed, 32 respondents (23.0\%) moderately disagreed, and 63 respondents $(45.3 \%)$ strongly disagreed with the statement.

"I attend volunteer training sessions for my personal growth and development" was the next statement. Thirty-five respondents (25.9\%) strongly agreed with the statement (see Table 2). Thirty-four respondents (25.2\%) moderately agreed, 35 respondents (25.9\%) slightly agreed, 15 respondents (11.1\%) slightly disagreed, four respondents (3.0\%) moderately disagreed, and 12 respondents $(8.9 \%)$ strongly disagreed with the statement. 
Table 2

4-H Club Leaders’ Attitudes toward 4-H Volunteer Training

\begin{tabular}{|c|c|c|c|c|c|c|c|c|c|c|c|c|}
\hline & \multicolumn{2}{|c|}{$\begin{array}{l}\text { Strongly } \\
\text { Disagree }\end{array}$} & \multicolumn{2}{|c|}{$\begin{array}{l}\text { Moderately } \\
\text { Disagree }\end{array}$} & \multicolumn{2}{|c|}{$\begin{array}{l}\text { Slightly } \\
\text { Disagree }\end{array}$} & \multicolumn{2}{|c|}{ Slightly Agree } & \multicolumn{2}{|c|}{$\begin{array}{l}\text { Moderately } \\
\text { Agree }\end{array}$} & \multicolumn{2}{|c|}{$\begin{array}{l}\text { Strongly } \\
\text { Agree }\end{array}$} \\
\hline & $N$ & $\%$ & $N$ & $\%$ & $N$ & $\%$ & $N$ & $\%$ & $N$ & $\%$ & $N$ & $\%$ \\
\hline $\begin{array}{l}\text { Training is important to becoming a } \\
\text { volunteer club leader }\end{array}$ & 3 & 2.2 & 2 & 1.4 & 3 & 2.2 & 21 & 15.1 & 49 & 35.3 & 61 & 43.9 \\
\hline $\begin{array}{l}\text { Training is only for persons who have no } \\
\text { 4-H background }\end{array}$ & 72 & 52.2 & 19 & 13.8 & 18 & 13.0 & 14 & 10.1 & 12 & 8.7 & 3 & 2.2 \\
\hline Training is only for new volunteers & 75 & 54.7 & 25 & 18.2 & 20 & 14.6 & 11 & 8.0 & 4 & 2.9 & 2 & 1.5 \\
\hline $\begin{array}{l}\text { The amount of training my county offers is } \\
\text { adequate for learning how to be a club } \\
\text { leader }\end{array}$ & 13 & 9.4 & 20 & 14.5 & 24 & 17.4 & 35 & 25.4 & 27 & 19.6 & 19 & 13.8 \\
\hline $\begin{array}{l}\text { Yearly volunteer training sessions would } \\
\text { not be beneficial to club leaders }\end{array}$ & 63 & 45.3 & 32 & 23.0 & 27 & 19.4 & 5 & 3.6 & 7 & 5.0 & 5 & 3.6 \\
\hline $\begin{array}{l}\text { I attend volunteer training sessions for my } \\
\text { personal growth and development }\end{array}$ & 12 & 8.9 & 4 & 3.0 & 15 & 11.1 & 35 & 25.9 & 34 & 25.2 & 35 & 25.9 \\
\hline $\begin{array}{l}\text { I attend volunteer training sessions to } \\
\text { improve my knowledge about youth }\end{array}$ & 4 & 3.1 & 5 & 3.8 & 6 & 4.6 & 22 & 16.9 & 46 & 35.4 & 47 & 36.2 \\
\hline
\end{tabular}


Table 2 (Continued)

4-H Club Leaders’ Attitudes toward 4-H Volunteer Training

\begin{tabular}{|c|c|c|c|c|c|c|c|c|c|c|c|c|}
\hline & \multicolumn{2}{|c|}{$\begin{array}{l}\text { Strongly } \\
\text { Disagree }\end{array}$} & \multicolumn{2}{|c|}{$\begin{array}{l}\text { Moderately } \\
\text { Disagree }\end{array}$} & \multicolumn{2}{|c|}{$\begin{array}{l}\text { Slightly } \\
\text { Disagree }\end{array}$} & \multicolumn{2}{|c|}{ Slightly Agree } & \multicolumn{2}{|c|}{$\begin{array}{l}\text { Moderately } \\
\text { Agree }\end{array}$} & \multicolumn{2}{|c|}{$\begin{array}{l}\text { Strongly } \\
\text { Agree }\end{array}$} \\
\hline & $N$ & $\%$ & $N$ & $\%$ & $N$ & $\%$ & $N$ & $\%$ & $N$ & $\%$ & $N$ & $\%$ \\
\hline $\begin{array}{l}\text { I attend volunteer training sessions to } \\
\text { improve my knowledge about } 4-\mathrm{H}\end{array}$ & 3 & 2.3 & 5 & 3.8 & 2 & 1.5 & 31 & 23.5 & 43 & 32.6 & 48 & 36.4 \\
\hline $\begin{array}{l}\text { I attend volunteer training sessions to } \\
\text { improve my leadership abilities }\end{array}$ & 4 & 3.0 & 3 & 2.3 & 2 & 1.5 & 21 & 15.9 & 43 & 32.6 & 59 & 44.7 \\
\hline $\begin{array}{l}\text { I attend volunteer training sessions to } \\
\text { improve my attitudes about } 4-\mathrm{H}\end{array}$ & 21 & 15.9 & 6 & 4.5 & 16 & 12.1 & 25 & 18.9 & 27 & 20.5 & 37 & 28.0 \\
\hline $\begin{array}{l}\text { I attend volunteer training sessions to } \\
\text { obtain new activities for use in my club }\end{array}$ & 3 & 2.3 & 2 & 1.5 & 1 & .8 & 14 & 10.8 & 37 & 28.5 & 73 & 56.2 \\
\hline $\begin{array}{l}\text { I plan to attend more training sessions in } \\
\text { the future }\end{array}$ & 2 & 1.5 & 1 & .8 & 8 & 6.1 & 28 & 21.2 & 36 & 27.3 & 57 & 43.2 \\
\hline
\end{tabular}


Forty-seven respondents (36.2\%) strongly agreed with the statement, "I attend volunteer training sessions to improve my knowledge about youth (see Table 2). Fortysix respondents (35.4\%) moderately agreed, 22 respondents (16.9\%) slightly agreed, six respondents (4.6\%) slightly disagreed, five respondents (3.8\%) moderately disagreed, and four respondents (3.1\%) strongly disagreed with the statement.

"I attend volunteer training session to improve my knowledge about 4-H" had 48 respondents (36.4\%) in strong agreement (see Table 2). Forty-three respondents $(32.6 \%)$ moderately agreed, 31 respondents $(23.5 \%)$ slightly agreed, two respondents $(1.5 \%)$ slightly disagreed, five respondents (3.8\%) moderately disagreed, and three respondents (2.3\%) strongly disagreed with the statement.

The statement, "I attend volunteer training session to improve my leadership abilities," had 59 respondents (44.7\%) strongly agree with the comment (see Table 2 ). Forty-three respondents (32.6\%) moderately agreed, 21 respondents (15.9\%) slightly agreed, two respondents (1.5\%) slightly disagreed, three respondents $(2.3 \%)$ moderately disagreed, and four respondents (3.0\%) strongly disagreed with the statement.

Thirty-seven respondents (28.0\%) strongly agreed with the statement, "I attend volunteer training sessions to improve my attitudes about 4-H" (see Table 2). Twentyseven respondents $(20.5 \%)$ moderately agreed, 25 respondents (18.9\%) slightly agreed, 16 respondents (12.1\%) slightly disagreed, six respondents (4.5\%) moderately disagreed, and 21 respondents $(15.9 \%)$ strongly disagreed with the statement.

"I attend volunteer training session to obtain new activities for use in my club" had $56.7 \%$ of the respondents $(N=73)$ strongly agree with the comment (see Table 2$)$. Thirty-seven respondents $(28.5 \%)(N=37)$ moderately agreed, 10.8 of the respondents 
$(N=14)$ slightly agreed, $0.8 \%$ of the respondents $(N=1)$ slightly disagreed, $1.5 \%$ of the respondents $(N=2)$ moderately disagreed, and $2.3 \%$ of the respondents $(N=3)$ strongly disagreed with the statement.

Fifty-seven respondents (43.2\%) strongly agreed with the statement "I plan to attend more training sessions in the future" (see Table 2). Thirty-six respondents (27.3\%) moderately agreed, 28 respondents (21.2\%) slightly agreed, eight respondents (6.1\%) slightly disagreed, one respondent $(0.8 \%)$ moderately disagreed, and two respondents (1.5\%) strongly disagreed with the statement.

\section{4-H Volunteer Training Participation and Needs}

Respondents were asked to respond to a series of questions about training topics related to 4-H and club work. First they were to identify if they have had prior training on the specified topics. Then they were to decide if they would like to have training on these same topics in the future. The following sections reflect their responses.

Prior Training on Club Mechanics. The respondents first replied to questions that related to the mechanics of a $4-\mathrm{H}$ club. Ninety respondents $(68.2 \%)$ had received training on program planning, 97 respondents $(71.9 \%)$ had received training on club organization, 75 respondents (57.3\%) had training on agenda building, 74 respondents (56.1\%) indicated they had receiving training in committee functions, and 96 individuals (71.6\%) had been trained in the 4-H club meeting (see Table 3).

One hundred two respondents $(76.1 \%)$ had been trained in parliamentary procedure, 83 respondents $(65.1 \%)$ were trained in events - opportunities for members, 80 respondents (63.5\%) indicated that they had received training in events—opportunities for leaders, and 15 individual (51.7\%) had been trained in other areas of club mechanics 
(see Table 3). Four topics were written in this category. They were project books; game leader, song leader, \& project helper; basic manners; and camp counseling.

Table 3

4-H Club Leaders Prior Training on Club Mechanics

\begin{tabular}{lcccc}
\hline & \multicolumn{2}{c}{ Yes } & \multicolumn{3}{c}{ No } \\
& $N$ & $\%$ & $N$ & $\%$ \\
\hline Program planning & 90 & 68.2 & 42 & 31.8 \\
Club organization & 97 & 71.9 & 38 & 28.1 \\
Agenda building & 75 & 57.3 & 56 & 42.7 \\
Committee functions & 74 & 56.1 & 58 & 43.9 \\
The 4-H Club meeting & 96 & 71.6 & 38 & 28.4 \\
Parliamentary procedure & 102 & 76.1 & 32 & 23.9 \\
Events-opportunities for & & & & \\
members & 82 & 65.1 & 44 & 34.9 \\
Events-opportunities for leaders & 80 & 63.5 & 46 & 36.5 \\
Other: & 15 & 51.7 & 14 & 48.3 \\
\hline
\end{tabular}

Prior Training on Leadership Roles. The respondents were asked questions about their training on leadership roles as a 4-H volunteer leader. On the topic, recruitment of 4-H members, $51.5 \%$ of the respondents $(N=69)$ indicated that they had received training (see Table 4). On recruitment of 4-H leaders, $39.7 \%$ of the respondents $(N=52)$ replied that they had received training on this topic. Sixty-eight respondents $(52.3 \%)$ responded that they had received training on working with teen leaders. Ninety-five respondents (71.4\%) answered "yes" to receiving training on the role of the 4-H leader. On the topic, understanding youth, 90 respondents $(67.2 \%)$ responded that they had received training 
(see Table 4). Seven respondents (33.3\%) indicated other leadership roles training. One respondent wrote in a topic for other, which stated "How friendliness is a basic concept and need."

Table 4

4-H Club Leaders Prior Training on Leadership Roles

\begin{tabular}{lcccc}
\hline & \multicolumn{2}{c}{ Yes } & \multicolumn{2}{c}{ No } \\
& $N$ & $\%$ & $N$ & $\%$ \\
\hline $\begin{array}{l}\text { Recruitment of 4-H } \\
\text { members }\end{array}$ & 69 & 51.5 & 65 & 48.5 \\
Recruitment of 4-H leaders & 52 & 39.7 & 79 & 60.3 \\
Working with teen leaders & 68 & 52.3 & 62 & 47.7 \\
Role of the 4-H leader & 95 & 71.4 & 38 & 28.6 \\
Understanding youth & 90 & 67.2 & 44 & 32.8 \\
Other: & 7 & 33.3 & 14 & 66.7 \\
\hline
\end{tabular}

Prior Training on Public Relations. In the next category respondents were asked about training in public relations topics. Fifty-one respondents $(38.9 \%)$ responded that they have had training on building exhibits. While on the topic of demonstrations, $61.4 \%$ of the respondents $(N=81)$ said they had received training. For public speaking, 76 respondents (57.6\%) said they had received training on the topic. Eighty respondents $(60.6 \%)$ indicated that they had received training on working with adults. One hundred three respondents $(77.4 \%)$ replied that they have received training on working with youth. On the topic of community service, $68.9 \%$ of the respondents $(N=91)$ indicated they had received training (see Table 5). Seven respondents $(29.2 \%)$ indicated training in 
other public relations topics. The one written-in response stated, "Learning how to get along," in this category.

Table 5

4-H Club Leaders Prior Training on Public Relations

\begin{tabular}{lcccc}
\hline & \multicolumn{2}{c}{ Yes } & \multicolumn{2}{c}{ No } \\
& $N$ & $\%$ & $N$ & $\%$ \\
\hline Building exhibits & 51 & 38.9 & 80 & 61.1 \\
Demonstrations & 81 & 61.4 & 51 & 38.6 \\
Public speaking & 76 & 57.6 & 56 & 42.4 \\
Working with adults & 80 & 60.6 & 52 & 39.4 \\
Working with youth & 103 & 77.4 & 30 & 22.6 \\
Community service & 91 & 68.9 & 41 & 31.1 \\
Other: & 7 & 29.2 & 17 & 70.8 \\
\hline
\end{tabular}

Prior Training on Volunteer Leader Training. The respondents were asking to indicate prior training related to topics that volunteer leaders need to run a 4-H club. One hundred four respondents $(78.8 \%)$ indicated that they had received training on the purpose of 4-H. In the category, use of the 4-H name and emblem, 107 respondents (79.9\%) responded "yes" to training. Eighty-nine respondents $(67.4 \%)$ indicated that they have received training on teaching tools and techniques. On the topic of developing 4-H programs, $59.2 \%$ of the respondents $(N=77)$ responded that they had received training. Eighty-six respondents $(65.2 \%)$ replied that they had received training on handling funds in 4-H organizations (see Table 6). Nine respondents (36.0\%) indicated 
other volunteer leader training opportunities. Two written responses were provided. They were "more on charting" and "basic check writing skills and balancing a checkbook." Table 6

4-H Club Leaders Prior Training on Volunteer Leader Training

\begin{tabular}{lcccc}
\hline & \multicolumn{2}{c}{ Yes } & \multicolumn{2}{c}{ No } \\
& $N$ & $\%$ & $N$ & $\%$ \\
\hline Purpose of 4-H & 104 & 78.8 & 28 & 21.2 \\
Use of the 4-H name and emblem & 107 & 79.9 & 27 & 20.1 \\
Teaching tools and techniques & 89 & 67.4 & 43 & 32.6 \\
Developing 4-H programs & 77 & 59.2 & 53 & 40.8 \\
Handling funds in 4-H organizations & 86 & 65.2 & 46 & 34.8 \\
Other: & 9 & 36.0 & 16 & 64.0 \\
\hline
\end{tabular}

Prior Training on Subject Matter Topics. The respondents were asked to indicate training related to the topics covered in the project books that the 4-H members complete. Forty-two respondents (33.9\%) responded that they have had training on animal science. Thirty-two respondents $(25.0 \%)$ responded that they have had training on plant science and crops. On the topic of mechanical science, $15.0 \%$ of the respondents $(N=19)$ indicated that they had training. Fifty-two respondents $(41.6 \%)$ replied that they have had training in natural resources and environment. In the subject area, leadership and community involvement, 76 respondents $(60.8 \%)$ reported having received training. Eighty-nine respondents (68.5\%) indicated they had received training in health and safety. In the category, individual and family resources, $43.2 \%$ of the respondents $(N=54)$ stated that they have had training. Thirty-eight respondents $(30.9 \%)$ replied that 
they have received training in the area of communication arts and sciences (see Table 7). Five respondents $(23.8 \%)$ indicated other subject matter training opportunities. Two responses were written under "other" by two different respondents. They were "horse club" and "teach volunteerism (younger people do not volunteer as much as us older ones-they want to be paid!!).”

Table 7

4-H Club Leaders Prior Training on Subject Matter

\begin{tabular}{lcccc}
\hline & \multicolumn{2}{c}{ Yes } & \multicolumn{2}{c}{ No } \\
& $N$ & $\%$ & 82 & 66.1 \\
\hline Animal science & 42 & 33.9 & 96 & 75.0 \\
Plant science and crops & 32 & 25.0 & 108 & 85.0 \\
Mechanical science & 19 & 15.0 & 73 & 58.4 \\
Natural resources and environment & 52 & 41.6 & 49 & 39.2 \\
Leadership and community & 76 & 60.8 & & 31.5 \\
involvement & & & 41 & 56.8 \\
Health and safety & 89 & 68.5 & 71 & 69.1 \\
Individual and family resources & 54 & 43.2 & 85 & 76.2 \\
Communication arts and sciences & 38 & 30.9 & 16 & \\
Other: & 5 & 23.8 & & \\
\hline
\end{tabular}

Prior Training on Leisure Education. The respondents responded to questions about leisure educational training opportunities available in 4-H. Eighty-three respondents $(64.3 \%)$ responded that they have received training in recreation. In the category, song leading, 77 respondents $(59.7 \%)$ replied that they have received training. Under the subject, camping, $68.2 \%$ of the respondents $(N=88)$ indicated that they have 
received training (see Table 8 ). Seven respondents $(28.0 \%)$ indicated other leisure education trainings. Four write-in topics were received from three different respondents. One respondent wrote in "starting a fire and cooking in the rain while camping." The other two write-in statements were shooting sports and indoor games.

Table 8

4-H Club Leaders Prior Training on Leisure Education

\begin{tabular}{lcccc}
\hline & \multicolumn{2}{c}{ Yes } & \multicolumn{2}{c}{ No } \\
& $N$ & $\%$ & $N$ & $\%$ \\
\hline Recreation & 83 & 64.3 & 46 & 35.7 \\
Song leading & 77 & 59.7 & 52 & 40.3 \\
Camping & 88 & 68.2 & 41 & 31.8 \\
Other: & 7 & 28.0 & 18 & 72.0 \\
\hline
\end{tabular}

Prior Training on Skills 4-H Youth Learn. The respondents were asked to indicate training in the skills 4-H members learn. Seventy-eight respondents $(61.9 \%)$ indicated that they have received training in decision making. Seventy-eight respondents $(61.4 \%)$ indicated that they have received training on social responsibility. On valuing diversity, $61.3 \%$ of the respondents $(N=76)$ replied that they have received training. Ninety-one respondents $(71.1 \%)$ indicated receiving training on leadership skills. For problemsolving, 82 respondents $(66.7 \%)$ responded has having received training in this area. Seventy-seven respondents $(62.1 \%)$ indicated that they have received training on relationship-building. In the category, critical thinking, 71 respondents $(57.7 \%)$ replied that they have had training in this area. Eighty-one respondents $(64.3 \%)$ responded that they had training in communication. Under conflict resolution, 76 respondents $(60.3 \%)$ 
replied "yes" to having received training. In the category, goal-setting, 79 respondents $(62.7 \%)$ replied that they had received training. Under planning, $66.1 \%$ of the respondents $(N=84)$ replied "yes" to receiving training. Eighty-seven respondents (67.4) indicated that they had received training in personal safety (see Table 9).

In the category, other, seven respondents (30.4\%) indicated other training in skills 4-H youth learn (see Table 9). Two responses were written under other by two different respondents. These topics were "several of above as part of shooting sports" and "how not to get into credit card debt."

Want Training on Club Mechanics. Respondents were asked if they wanted training on club mechanics topics. Seventy-three respondents (71.6\%) indicated they wanted training on program planning. In the category, club organization, 51 respondents (54.3\%) replied that they wanted more training. For agenda building, 48 respondents (49.10\%) responded "yes" to wanting additional training. Fifty-two respondents (53.1\%) indicated that they wanted training in committee functions. On the subject of the 4-H club meeting, 45 respondents (49.5\%) replied "yes" to wanting more training. Fifty-five respondents $(58.5 \%)$ responded that they wanted more training on parliamentary procedure. For the question, events—opportunities for members, 67 respondents $(69.1 \%)$ wanted more training. Under events — opportunities for leaders, $64.2 \%$ of the respondents ( $N=61)$ wanted training on this topic (see Table 10). For the category, other, eleven respondents (47.8\%) responded "yes." No additional information was provided. 
Table 9

4-H Club Leaders Prior Training on Skills 4-H Youth Learn

\begin{tabular}{|c|c|c|c|c|}
\hline & \multicolumn{2}{|c|}{ Yes } & \multicolumn{2}{|c|}{ No } \\
\hline & $N$ & $\%$ & $N$ & $\%$ \\
\hline Decision making & 78 & 61.9 & 48 & 38.1 \\
\hline Social responsibility & 78 & 61.4 & 49 & 38.6 \\
\hline Valuing diversity & 76 & 61.3 & 48 & 38.7 \\
\hline Leadership skills & 91 & 71.1 & 37 & 28.9 \\
\hline Problem-solving & 82 & 66.7 & 41 & 33.3 \\
\hline Relationship-building & 77 & 62.1 & 47 & 37.9 \\
\hline Critical thinking & 71 & 57.7 & 52 & 42.3 \\
\hline Communication & 81 & 64.3 & 45 & 35.7 \\
\hline Conflict resolution & 76 & 60.3 & 50 & 39.7 \\
\hline Goal-setting & 79 & 62.7 & 47 & 37.3 \\
\hline Planning & 84 & 66.1 & 43 & 33.9 \\
\hline Personal safety & 87 & 67.4 & 42 & 32.6 \\
\hline Other: & 7 & 30.4 & 16 & 69.6 \\
\hline
\end{tabular}


Table 10

4-H Club Leaders’ Desires for Training on Club Mechanics Topics

\begin{tabular}{lcccc}
\hline & \multicolumn{2}{c}{ Yes } & $\%$ & \multicolumn{2}{c}{ No } \\
& 73 & 71.6 & 29 & 28.4 \\
\hline Program planning & 51 & 54.3 & 43 & 45.7 \\
Club organization & 48 & 49.0 & 50 & 51.0 \\
Agenda building & 52 & 53.1 & 46 & 46.9 \\
Committee functions & 45 & 49.5 & 46 & 50.5 \\
The 4-H Club meeting & 55 & 58.5 & 39 & 41.5 \\
Parliamentary procedure & 67 & 69.1 & 30 & 30.9 \\
Events-opportunities for members & 61 & 64.2 & 34 & 35.8 \\
Events-opportunities for leaders & 11 & 47.8 & 12 & 52.2 \\
\hline Other: & & & & \\
\hline
\end{tabular}

Want Training on Leadership Roles. Fifty-three respondents (54.1\%) indicated that they wanted more training on recruitment of 4-H members. For recruitment of 4-H leaders, 54 respondents $(54.5 \%)$ replied that they wanted training. In the category, working with teen leaders, $63.3 \%$ of the respondents $(N=62)$ responded that they wanted training. Forty-nine respondents $(54.4 \%)$ replied "yes" to wanting training on the role of the 4-H leader. For understanding youth, $67.0 \%$ of the respondents $(N=63)$ wanted more training (see Table 11). In the category, other, eight respondents $(42.1 \%)$ responded "yes" to additional training in the category. 
Table 11

4-H Club Leaders’ Desires for Training on Leadership Roles Topics

\begin{tabular}{lcccc}
\hline & \multicolumn{2}{c}{ Yes } & \multicolumn{2}{c}{ No } \\
& $N$ & $\%$ & $N$ & $\%$ \\
\hline $\begin{array}{l}\text { Recruitment of 4-H } \\
\text { members }\end{array}$ & 53 & 54.1 & 45 & 45.9 \\
Recruitment of 4-H leaders & 54 & 54.5 & 45 & 45.5 \\
Working with teen leaders & 62 & 63.3 & 36 & 36.7 \\
Role of the 4-H leader & 49 & 54.4 & 41 & 45.6 \\
Understanding youth & 63 & 67.0 & 31 & 33.0 \\
Other: & 8 & 42.1 & 11 & 57.9 \\
\hline
\end{tabular}

Want Training on Public Relations. Fifty-six respondents (57.1\%) responded that they wanted training on building exhibits. On the topic, demonstrations, $50.0 \%$ of the respondents $(N=47)$ said they wanted training. For public speaking, 49 respondents $(51.0 \%)$ said they wanted training on the topic. Forty-two respondents $(45.7 \%)$ indicated they wanted training on working with adults. Forty-eight respondents (52.7\%) replied that they wanted training on working with youth. On the topic of community service, $55.8 \%$ of the respondents $(N=53)$ responded "yes" to additional training (see Table 12$)$. In the category, other, six respondents $(30.0 \%)$ replied "yes" to additional training in the category. 
Table 12

4-H Club Leaders’ Desires for Training on Public Relations Topics

\begin{tabular}{lcccc}
\hline & \multicolumn{2}{c}{ Yes } & \multicolumn{2}{c}{ No } \\
& $N$ & $\%$ & 42 & 42.9 \\
\hline Building exhibits & 56 & 57.1 & 47 & 50.0 \\
Demonstrations & 47 & 50.0 & 47 & 49.0 \\
Public speaking & 49 & 51.0 & 50 & 54.3 \\
Working with adults & 42 & 45.7 & 43 & 47.3 \\
Working with youth & 48 & 52.7 & 42 & 44.2 \\
Community service & 53 & 55.8 & 14 & 70.0 \\
Other: & 6 & 30.0 & & \\
\hline
\end{tabular}

Want Training on Volunteer Leader Training. Thirty-seven respondents (40.7\%) responded that they wanted training on the purpose of 4-H. In the category, use of the 4H name and emblem, 44 respondents (46.8\%) responded "yes" to wanting additional training. Fifty-eight respondents $(60.4 \%)$ indicated that they wanted more training on teaching tools and techniques. On the topic, developing $4-\mathrm{H}$ programs, $63.3 \%$ of the respondents $(N=62)$ responded that they wanted training. Fifty respondents $(53.8 \%)$ replied that they want more training on handling funds in 4-H organizations (see Table 13). In the category, other, seven respondents (28.0\%) replied "yes" to additional training. 
Table 13

4-H Club Leaders' Desires for Training on Volunteer Reader Training Topics

\begin{tabular}{lcccc}
\hline & \multicolumn{2}{c}{ Yes } & \multicolumn{2}{c}{ No } \\
& $N$ & $\%$ & $N$ & $\%$ \\
\hline Purpose of 4-H & 37 & 40.7 & 54 & 59.3 \\
Use of the 4-H name and emblem & 44 & 46.8 & 50 & 53.2 \\
Teaching tools and techniques & 58 & 60.4 & 38 & 39.6 \\
Developing 4-H programs & 62 & 63.3 & 36 & 36.7 \\
Handling funds in 4-H & 50 & 53.8 & 43 & 46.2 \\
organizations & & & & \\
Other: & 7 & 28.0 & 18 & 72.0 \\
\hline
\end{tabular}

Want Training on Subject Matter. For animal science, 37 respondents (38.5\%) indicated they wanted training on the topic. Thirty-nine individuals (39.0\%) responded that they wanted training on the subject of plant science and crops. On the topic of mechanical science, $33.3 \%$ of the respondents $(N=33)$ indicated that they wanted additional training. Forty-eight respondents $(49.0 \%)$ replied that they wanted training in the area of natural resources and environment. In the subject area of leadership and community involvement, 56 respondents (58.9\%) reported that they wanted additional training. Fifty-two respondents (56.5\%) responded "yes" to wanting training in health and safety. In the category individual and family resources, $55.7 \%$ of the respondents $(N=54)$ stated that they wanted more training. Forty-seven respondents $(47.0 \%)$ replied that they wanted training in the area of communication arts and sciences (see Table 14). 
In the category, other, six respondents $(28.6 \%)$ responded "yes" to other training in this category.

Table 14

4-H Club Leaders’ Desires for Training on Subject Matter Topics

\begin{tabular}{lcccc}
\hline & \multicolumn{2}{c}{ Yes } & \multicolumn{3}{c}{ No } \\
& $N$ & $\%$ & 59 & 61.5 \\
\hline Animal science & 37 & 38.5 & 61 & 61.0 \\
Plant science and crops & 39 & 39.0 & 66 & 66.7 \\
Mechanical science & 33 & 33.3 & 50 & 51.0 \\
Natural resources and environment & 48 & 49.0 & 39 & 41.1 \\
Leadership and community & 56 & 58.9 & & \\
involvement & & & 40 & 43.5 \\
Health and safety & 52 & 56.5 & 43 & 44.3 \\
Individual and family resources & 54 & 55.7 & 53 & 53.0 \\
Communication arts and sciences & 47 & 47.0 & 15 & 71.4 \\
\hline Other: & 6 & 28.6 & & \\
\hline
\end{tabular}

Want Training on Leisure Education. Fifty one respondents (53.7\%) responded that they wanted more training in recreation. In the category of song leading, 49 respondents $(50.0 \%)$ responded "yes" to wanting training (see Table 15). For camping, $51.1 \%$ of the respondents $(N=48)$ replied that they wanted training on the topic. In the category, other, seven respondents (29.2\%) replied "yes" to additional training. 
Table 15

4-H Club Leaders’ Desires for Training on Leisure Education Topics

\begin{tabular}{lcccc}
\hline & \multicolumn{2}{c}{ Yes } & \multicolumn{2}{c}{ No } \\
& $N$ & $\%$ & $N$ & $\%$ \\
\hline Recreation & 51 & 53.7 & 44 & 46.3 \\
Song leading & 49 & 50.0 & 49 & 50.0 \\
Camping & 48 & 51.1 & 46 & 48.9 \\
Other: & 7 & 29.2 & 17 & 70.8 \\
\hline
\end{tabular}

Want Training on Skills 4-H Youth Learn. In the category of decision making, 60 respondents $(61.9 \%)$ indicated that they wanted training. Sixty-one respondents $(62.2 \%)$ indicated that they wanted training on social responsibility. On valuing diversity, $61.1 \%$ of the respondents $(N=58)$ replied that they wanted more training. Fifty-eight respondents $(60.4 \%)$ replied "yes" to wanting training on leadership skills. For problemsolving, 58 respondents $(59.8 \%)$ responded that they wanted training in this area. Fiftynine respondents $(62.8 \%)$ indicated that they wanted training on relationship-building. In the category of critical thinking, 54 respondents $(58.1 \%)$ replied that they did want more training in this area. Sixty-two respondents (63.9\%) responded that they wanted training in communication. Under conflict resolution, 60 respondents $(62.5 \%)$ replied "yes" to wanting training. In the category, goal-setting, 55 respondents $(57.9 \%)$ replied that they wanted more training. Under planning, $56.5 \%$ of the respondents $(N=52)$ replied "yes" to wanting training. Fifty respondents $(54.9 \%)$ indicated that they wanted training in personal safety (see Table 16). In the category, other, fifteen respondents (62.5\%) replied "yes" to additional training. 
Table 16

4-H Club Leaders’ Desires for Training on Skills 4-H Youth Learn Topics

\begin{tabular}{|c|c|c|c|c|}
\hline & \multicolumn{2}{|c|}{ Yes } & \multicolumn{2}{|c|}{ No } \\
\hline & $N$ & $\%$ & $N$ & $\%$ \\
\hline Decision making & 60 & 61.9 & 37 & 38.1 \\
\hline Social responsibility & 61 & 62.2 & 37 & 37.8 \\
\hline Valuing diversity & 58 & 61.1 & 37 & 38.9 \\
\hline Leadership skills & 58 & 60.4 & 38 & 39.6 \\
\hline Problem-solving & 58 & 59.8 & 39 & 40.2 \\
\hline Relationship-building & 59 & 62.8 & 35 & 37.2 \\
\hline Critical thinking & 54 & 58.1 & 39 & 41.9 \\
\hline Communication & 62 & 63.9 & 35 & 36.1 \\
\hline Conflict resolution & 60 & 62.5 & 36 & 37.5 \\
\hline Goal-setting & 55 & 57.9 & 40 & 42.1 \\
\hline Planning & 52 & 56.5 & 40 & 43.5 \\
\hline Personal safety & 50 & 54.9 & 41 & 45.1 \\
\hline Other: & 15 & 62.5 & 9 & 37.5 \\
\hline
\end{tabular}

Method or Delivery Technique Desired for Training

The respondents were asked to indicate what types of training methods suited them best. Hands-on participation had the most respondents with 114 (87.7\%) (see Table 17). The second responses most desired training method was a single county meeting with 113 respondents $(86.3 \%)$. The third highest method was handbook with a total of $85.0 \%(N=108)$ of the respondents. The newsletter method was not far behind with 107 
respondents $(84.9 \%)$ replying "yes" to this technique. The method, workshop-multiple topic, had 103 respondents $(79.8 \%)$ indicate "yes." The other methods included group discussion $(N=102,81.9=0 \%)$, extension bulletin $(N=98,77.8 \%)$, multicounty meetings $(N=96,75.6 \%)$, workshop-single topic $(N=92,73.6 \%)$, presentation or lecture $(N=81,66.4 \%)$, pre-recorded video $(N=77,64.2 \%)$, Internet based course $(N=75,60.5 \%)$, weekend training conference $(N=69,55.2 \%)$, regional meetings $(N=62$, $50.8 \%)$, statewide meetings $\quad(N=54,45.0 \%)$, pre-recorded audio $(N=53,44.9 \%)$ (see Table 17). The category, other, had four "yes" respondents (40.0\%).

\section{Ranked Training Method or Technique}

The respondents were then asked to rank their top five preferred delivery methods. A first choice received five votes, second choice four votes, third choice three votes, four choice two votes, and fifth choice one vote. Based on their rankings, single county meetings had a sum of 249 votes with 26 respondents $(37.1 \%)$ ranking it as their first choice, 16 respondents $(22.9 \%)$ as their second choice, 10 respondents $(14.3 \%)$ as their third choice, seven respondents $(10.0 \%)$ as their fourth choice, and eleven respondents (15.7\%) as their fifth choice (see Table 18). 
Table 17

4-H Club Leaders’ Preferences for Training Methods or Delivery Techniques

\begin{tabular}{|c|c|c|c|c|}
\hline & \multicolumn{2}{|c|}{ Yes } & \multicolumn{2}{|c|}{ No } \\
\hline & $N$ & $\%$ & $N$ & $\%$ \\
\hline Hands-on participation & 114 & 87.7 & 16 & 12.3 \\
\hline Single county meeting & 113 & 86.3 & 18 & 13.7 \\
\hline Handbook & 108 & 85.0 & 19 & 15.0 \\
\hline Newsletter & 107 & 84.9 & 19 & 15.1 \\
\hline Workshop - multiple topic & 103 & 79.8 & 26 & 20.2 \\
\hline Group discussion & 102 & 81.0 & 24 & 19.0 \\
\hline Extension bulletin & 98 & 77.8 & 28 & 22.2 \\
\hline Multicounty meetings & 96 & 75.6 & 31 & 24.4 \\
\hline Workshop - single topic & 92 & 73.6 & 33 & 26.4 \\
\hline Presentation or lecture & 81 & 66.4 & 41 & 33.6 \\
\hline Pre-recorded video & 77 & 64.2 & 43 & 35.8 \\
\hline Internet based course & 75 & 60.5 & 49 & 39.5 \\
\hline $\begin{array}{l}\text { Weekend training } \\
\text { conference }\end{array}$ & 69 & 55.2 & 56 & 44.8 \\
\hline Regional meetings & 62 & 50.8 & 60 & 49.2 \\
\hline Statewide meetings & 54 & 45.0 & 66 & 55.0 \\
\hline Pre-recorded audio & 53 & 44.9 & 65 & 55.1 \\
\hline Other: & 4 & 40.0 & 6 & 60.0 \\
\hline
\end{tabular}

Multicounty meetings received the second highest sum of 189 votes with 14 respondents $(25.5 \%)$ choosing it as their first choice, 12 respondents $(21.8 \%)$ as their 
second choice, 19 respondents $(34.5 \%)$ as their third choice, four respondents $(7.3 \%)$ as their fourth choice, and six respondents (10.9\%) as their fifth choice (see Table 18). Hands-on participation received a sum of 178 votes (see Table 18). Seventeen respondents $(29.8 \%)$ chose this method as their first choice, nine respondents $(15.8 \%)$ as their second choice, nine respondents $(15.8 \%)$ as their third choice, eight respondents $(14.0 \%)$ as their fourth choice, and 14 respondents $(24.6 \%)$ as their fifth choice (see Table 18).

Nine respondents (18.8\%) chose handbook as their first choice delivery method (see Table 18). Thirteen respondents (27.1\%) chose it as their second choice and seven respondents (14.6\%) chose it as their third choice. Ten respondents (20.8\%) chose this method as their fourth choice and nine respondents (18.8\%) chose it as their fifth choice. Handbook received a sum of 147 (see Table 18).

Internet based courses received a sum of 134 with 14 first choice respondents (35.9\%), eight second choice respondents (20.5\%), five third place respondents $(12.8 \%)$, five fourth place respondents (12.8\%), and seven fifth place respondents (17.9\%) (see Table 18). The delivery method, workshop - multiple topic, had a total sum of 129 with seven respondents (14.6\%) choosing it as their first choice, four respondents (8.3\%) choosing it as their second choice, 13 respondents $(27.1 \%)$ choosing it as their third choice, 15 respondents (31.3\%) choosing it as their fourth choice, and nine respondents (18.9\%) choosing it as their fifth choice (see Table 18).

Four respondents (11.1\%) chose group discussion as their first choice delivery method (see Table 18). Nine respondents (25.0\%) chose this method as their second choice, three respondents (8.3\%) as their third choice, 14 respondents (38.9\%) as their 
fourth choice, and six respondents (16.7\%) as their fifth choice. Group discussion had a total sum of 99 (see Table 18).

The category, workshop-single topic, received a sum of 96 with four respondents (12.1\%) choosing it as their first choice, nine respondents (27.3\%) as their second choice, six respondents (18.2\%) as their third choice, eight respondents $924.2 \%)$ as their fourth choice, and six respondents (18.2\%) as their fifth choice (see Table 18).

Pre-recorded video had a total sum of 91 due to six respondents (18.2\%) choosing this method as their first choice (see Table 18). Six respondents (18.2\%) chose it as their second choice, three respondents $(9.1 \%)$ chose it as their third choice, 10 respondents (30.3\%) chose it as their fourth choice, and eight respondents (24.2\%) chose it as their fifth choice.

Weekend training conference received a sum of 88 votes from seven first choice respondents (22.6\%), six second choice respondents (19.4\%), two third choice respondents (6.5\%), seven fourth choice respondents (22.6\%), and nine fifth choice respondents (29.0\%) (see Table 18). Six respondents (20.7\%) chose newsletter as their first choice delivery method (see Table 18$)$. Three respondents (10.3\%) chose this method as their second choice, nine respondents (31.0\%) chose this method as their third choice, three respondents (10.3\%) chose this method as their fourth choice, and eight respondents (27.6\%) chose this method as their fifth choice. Newsletter received a sum of 83 (see Table 18).

The delivery method, extension bulletin, received a sum of 79 with two respondents $(6.7 \%)$ choosing it as their first choice, six respondents $(20.0 \%)$ as their second choice, eight respondents (26.7\%) as their third choice, seven respondents 
(23.3\%) as their fourth choice, and seven respondents (23.3\%) as their fifth choice (see Table 18).

Regional meetings received a sum of 70 votes with three first choice respondents (13.0\%), five second choice respondents (21.7\%), eight third choice respondents (34.8\%), four fourth choice respondents (17.4\%), and three fifth place respondents (13.0\%) (see Table 18). Statewide meetings had a total sum of 45 with four respondents (23.5\%) who chose it as their first choice, three respondents (17.6\%) who chose it as their third choice, six respondents (3.53\%) who chose it as their fourth choice, and four respondents $(23.5 \%)$ who chose it as their fifth choice (see Table 18).

For the delivery method, presentation or lecture, two respondents (11.1\%) chose it as their first choice, two respondents (11.1\%) chose it as their second choice, three respondents $(16.7 \%)$ chose it as their third choice, three respondents $(16.7 \%)$ chose it as their fourth choice, and eight respondents (44.4\%) chose it as their fifth choice (see Table 18). Presentation and lecture had a sum of 41 votes (see Table 18). 
Table 18

4-H Club Leaders’ Rankings of Training Methods or Delivery Techniques

\begin{tabular}{|c|c|c|c|c|c|c|c|c|c|c|c|}
\hline & \multicolumn{2}{|c|}{$\begin{array}{c}\text { First } \\
\text { Choice }\end{array}$} & \multicolumn{2}{|c|}{$\begin{array}{l}\text { Second } \\
\text { Choice }\end{array}$} & \multicolumn{2}{|c|}{$\begin{array}{l}\text { Third } \\
\text { Choice }\end{array}$} & \multicolumn{2}{|c|}{$\begin{array}{l}\text { Fourth } \\
\text { Choice }\end{array}$} & \multicolumn{2}{|c|}{$\begin{array}{c}\text { Fifth } \\
\text { Choice }\end{array}$} & \multirow[b]{2}{*}{ Sum } \\
\hline & $N$ & $\%$ & $N$ & $\%$ & $N$ & $\%$ & $N$ & $\%$ & $N$ & $\%$ & \\
\hline Single county meeting & 26 & 37.1 & 16 & 22.9 & 10 & 14.3 & 7 & 10.0 & 11 & 15.7 & 249 \\
\hline Multicounty meetings & 14 & 25.5 & 12 & 21.8 & 19 & 34.5 & 4 & 7.3 & 6 & 10.9 & 189 \\
\hline Hands-on participation & 17 & 29.8 & 9 & 15.8 & 9 & 15.8 & 8 & 14.0 & 14 & 24.6 & 178 \\
\hline Handbook & 9 & 18.8 & 13 & 27.1 & 7 & 14.6 & 10 & 20.8 & 9 & 18.8 & 147 \\
\hline Internet based course & 14 & 35.9 & 8 & 20.5 & 5 & 12.8 & 5 & 12.8 & 7 & 17.9 & 134 \\
\hline Workshop - multiple topic & 7 & 14.6 & 4 & 8.3 & 13 & 27.1 & 15 & 31.3 & 9 & 18.8 & 129 \\
\hline Group discussion & 4 & 11.1 & 9 & 25.0 & 3 & 8.3 & 14 & 38.9 & 6 & 16.7 & 99 \\
\hline Workshop - single topic & 4 & 12.1 & 9 & 27.3 & 6 & 18.2 & 8 & 24.2 & 6 & 18.2 & 96 \\
\hline Pre-recorded video & 6 & 18.2 & 6 & 18.2 & 3 & 9.1 & 10 & 30.3 & 8 & 24.2 & 91 \\
\hline $\begin{array}{l}\text { Weekend training } \\
\text { conference }\end{array}$ & 7 & 22.6 & 6 & 19.4 & 2 & 6.5 & 7 & 22.6 & 9 & 29.0 & 88 \\
\hline Newsletter & 6 & 20.7 & 3 & 10.3 & 9 & 31.0 & 3 & 10.3 & 8 & 27.6 & 83 \\
\hline Extension bulletin & 2 & 6.7 & 6 & 20.0 & 8 & 26.7 & 7 & 23.3 & 7 & 23.3 & 79 \\
\hline Regional meetings & 3 & 13.0 & 5 & 21.7 & 8 & 34.8 & 4 & 17.4 & 3 & 13.0 & 70 \\
\hline Statewide meetings & 4 & 23.5 & 0 & .0 & 3 & 17.6 & 6 & 35.3 & 4 & 23.5 & 45 \\
\hline Presentation or lecture & 2 & 11.1 & 2 & 11.1 & 3 & 16.7 & 3 & 16.7 & 8 & 44.4 & 41 \\
\hline Pre-recorded audio & 0 & .0 & 2 & 20.0 & 4 & 40.0 & 2 & 20.0 & 2 & 20.0 & 26 \\
\hline Other: & 0 & .0 & 1 & $\begin{array}{c}100 . \\
0\end{array}$ & 0 & .0 & 0 & .0 & 0 & .0 & 4 \\
\hline
\end{tabular}


The delivery method with the smallest sum was pre-recorded audio with a total sum of 26 (see Table 18). Two respondents (20.0\%) chose this method as their second choice, four respondents $(40.0 \%)$ chose this method as their third choice, two respondents $(20.0 \%)$ chose this method as their fourth choice, and two respondents $(20.0 \%)$ chose this method as their fifth choice. The category other received a sum of 4 with one respondent $(100.0 \%)$ choosing it as their second choice (see Table 18). This respondent wrote in national conference for all of USA (just think of all the new people you would meet!). Frequency of Participation in Training Activities

Respondents were asked to determine how frequently they should participate in training activities. They were allowed to check all categories that applied. For the category, monthly, 14 respondents (9.7\%) replied "yes" (see Table 19). Twelve respondents $(8.3 \%)$ responded "yes" to bi-monthly training (see Table 19). For quarterly training, $27.8 \%$ of the respondents $(N=40)$ indicated "yes" (see Table 19). Thirty-six respondents $(25.0 \%)$ responded "yes" to semi-annually training. For the category, annually, 37 respondents $(25.7 \%)$ responded "yes" (see Table 19). The highest percentage of "yes" responses, $40.3 \%$ of the respondents $(N=58)$, came in the category, as needed (see Table 19). 
Table 19

4-H Club Leaders Desired Frequency of Participation in Training Activities

\begin{tabular}{lcccc}
\hline & \multicolumn{2}{c}{ No } & \multicolumn{2}{c}{ Yes } \\
& $N$ & $\%$ & $N$ & $\%$ \\
\hline Monthly & 130 & 90.3 & 14 & 9.7 \\
Bi-monthly & 132 & 91.7 & 12 & 8.3 \\
Quarterly & 104 & 72.2 & 40 & 27.8 \\
Semi-annually & 108 & 75.0 & 36 & 25.0 \\
Annually & 107 & 74.3 & 37 & 25.7 \\
As needed & 86 & 59.7 & 58 & 40.3 \\
\hline
\end{tabular}

Preference of Training Delivery

The respondents were asked who they preferred to delivery the training. They could check any that applied. The highest percentage of "yes" responses, $64.6 \%$ of the respondents ( $N=93)$, was for county staff to a group delivery method (see Table 20). State specialist received the next highest percentage of $52.1 \%$ of the respondents $(N=75)$ saying "yes" (see Table 20). Sixty-seven respondents (46.5) prefer training delivered by program teams (see Table 20). The categories, 1 to 1 with county staff and 1 to 1 with another leader, had only 20 respondents (13.9\%) each that wanted this method of delivery (see Table 20). 
Table 20

4-H Club Leaders’ Preferences for Trainers

\begin{tabular}{|c|c|c|c|c|}
\hline & \multicolumn{2}{|c|}{ No } & \multicolumn{2}{|c|}{ Yes } \\
\hline & $N$ & $\%$ & $N$ & $\%$ \\
\hline County staff to a group & 51 & 35.4 & 93 & 64.6 \\
\hline State specialist & 69 & 47.9 & 75 & 52.1 \\
\hline Program teams & 77 & 53.5 & 67 & 46.5 \\
\hline 1 to 1 with county staff & 124 & 86.1 & 20 & 13.9 \\
\hline 1 to 1 with another leader & 124 & 86.1 & 20 & 13.9 \\
\hline Other: experts-professionals & 141 & 97.9 & 3 & 2.1 \\
\hline Other : Whoever -Any - doesn't matter & 141 & 97.9 & 3 & 2.1 \\
\hline Other: Weekend Training Conference & 143 & 99.3 & 1 & 0.7 \\
\hline $\begin{array}{l}\text { Other: Train the Trainer (Train one leader to train } \\
\text { other leaders in county) }\end{array}$ & 143 & 99.3 & 1 & 0.7 \\
\hline $\begin{array}{l}\text { Other: Someone who could relate to your specific } \\
\text { county }\end{array}$ & 143 & 99.3 & 1 & 0.7 \\
\hline Other: Other volunteers with much expertise & 143 & 99.3 & 1 & 0.7 \\
\hline Other: Other leader to group & 143 & 99.3 & 1 & 0.7 \\
\hline Other: NOTHING SPECIFIED & 143 & 99.3 & 1 & 0.7 \\
\hline Other: County Extension Agent & 143 & 99.3 & 1 & 0.7 \\
\hline Other: Community resource persons & 143 & 99.3 & 1 & 0.7 \\
\hline $\begin{array}{l}\text { Other: College 4-Her's, Junior Leaders, or other } \\
\text { teens which are trained to lead }\end{array}$ & 143 & 99.3 & 1 & 0.7 \\
\hline
\end{tabular}

Eleven answers were written in under the category, other. Only two of these eleven write-ins were listed by more than one respondent. Other: experts-professionals 
had three "yes" respondents (2.1\%). Also three respondents (2.1\%) wrote in the answer, other: Whoever-Any-Doesn't matter. The remaining nine write in answers received only one "yes" respondent $(0.7 \%)$. These write-in answers were weekend training conference; train the trainer (train one leader to train other leaders in county); someone who could relate to your specific county; other volunteers with much expertise; other leader to group; county extension agent; community resource persons; and college 4-Her's, junior leaders, or other teens which are trained to lead.

\section{Most Important Thing Learned at a Volunteer Training Session}

One of the two open-ended questions on this survey asked the respondents to identify the most important thing they have learned at a volunteer training session. Six respondents $(4.2 \%)$ responded that they have not had club leader training. Four respondents (2.8\%) indicated "yes" to learning about programs and activities. Four respondents (2.8\%) replied that they have learned new ideas. Four respondents $(2.8 \%)$ responded that they learned how to hold meetings. Using the logo and 4-H emblem was identified by three respondents (2.1\%). Three respondents (2.1\%) listed how to take care of 4-H funds. Three respondents (2.1\%) responded that how to deal with different abilities and needs was the most important thing they have learned (see Table 21). For a complete list of all responses to this question please refer to Appendix E. 
Table 21

Most Important Things Learned by 4-H Club Leaders at a Volunteer Training Session

\begin{tabular}{lcccc}
\hline & \multicolumn{2}{c}{ No } & \multicolumn{3}{c}{ Yes } \\
& $N$ & $\%$ & $N$ & $\%$ \\
\hline No club leader training & 138 & 95.8 & 6 & 4.2 \\
Programs and activities & 140 & 97.2 & 4 & 2.8 \\
New ideas & 140 & 97.2 & 4 & 2.8 \\
How to hold meetings & 140 & 97.2 & 4 & 2.8 \\
Use of logo and 4-H emblem & 141 & 97.9 & 3 & 2.1 \\
How to take care of 4-H funds & 141 & 97.9 & 3 & 2.1 \\
How to deal with different abilities and needs & 141 & 97.9 & 3 & 2.1 \\
\hline
\end{tabular}

Areas Volunteer Training Should Address More

The other open-ended question on this survey asked the respondents to identify areas volunteer training should address more. Nine respondents $(6.3 \%)$ identified projects books (help for completion) as an area that needs to be addressed. Seven respondents $(4.9 \%)$ stated that they wished training addressed program ideas more. Five respondents $(3.5 \%)$ responded that recruitment of volunteers was an area to address in training. Keeping parents involved in $4-\mathrm{H}$ was identified as a need by four respondents $(2.8 \%)$. Three respondents $(2.1 \%)$ replied that recruitment of members was a need to be addressed at training. Three respondents $(2.1 \%)$ indicated that project books (new \& revised) were a need to be addressed at training. Keeping kids involved in 4-H was identified by three respondents $(2.1 \%)$ as a need to be addressed at training. Three respondents $(2.1 \%)$ replied that inclusion/acceptance of all youth/leaders needed to be 
addressed. Three respondents $(2.1 \%)$ responded that there is a need at training to address the events and opportunities available for leaders and/or members. Three respondents (2.1\%) responded that controlling disruptive (challenge) children is a need (see Table 22).

For a complete list of all responses to this question please refer to Appendix F.

Table 22

4-H Club Leaders' Perceptions of Areas Volunteer Training Should Address More

\begin{tabular}{lcccc}
\hline & \multicolumn{2}{c}{ No } & \multicolumn{2}{c}{ Yes } \\
& $N$ & $\%$ & $N$ & $\%$ \\
\hline Project books--help for completion & 135 & 93.8 & 9 & 6.3 \\
Program ideas & 137 & 95.1 & 7 & 4.9 \\
Recruitment of volunteers & 139 & 96.5 & 5 & 3.5 \\
Keeping parents involved in 4-H & 140 & 97.2 & 4 & 2.8 \\
Recruitment of members & 141 & 97.9 & 3 & 2.1 \\
Project books--new \& revised & 141 & 97.9 & 3 & 2.1 \\
Keeping kids involved in 4-H & 141 & 97.9 & 3 & 2.1 \\
Inclusion/Acceptance of all youth/leaders & 141 & 97.9 & 3 & 2.1 \\
Events and Opportunities for leaders and/or & 141 & 97.9 & 3 & 2.1 \\
members & & & & \\
Controlling disruptive (challenge) children & 141 & 97.9 & 3 & 2.1 \\
\hline
\end{tabular}

\section{Demographic Characteristics}

Gender. Twenty two respondents (15.3\%) reported themselves as males while 120 respondents $(83.3 \%)$ reported to be females (see Table 23$)$. Two respondents $(1.4 \%)$ declined to answer this question. 
Table 23

Gender of 4-H Club Leaders

\begin{tabular}{lcc}
\hline Categories & $N$ & $\%$ \\
\hline Male & 22 & 15.3 \\
Female & 120 & 83.3 \\
Missing Value & 2 & 1.4 \\
\hline Total & 144 & 100.0 \\
\hline
\end{tabular}

Years as a 4-H Volunteer. Eight respondents (5.6\%) had been a 4-H volunteer for 0-2 years (see Table 24$)$. Thirty-three respondents $(22.9 \%)$ had been $4-\mathrm{H}$ volunteers for 3-5 years and 32 respondents $(22.2 \%)$ have been $4-\mathrm{H}$ volunteers for $6-10$ years. Fifteen respondents $(10.4 \%)$ had been $4-\mathrm{H}$ volunteers for $11-15$ years and 54 respondents (37.5\%) had been 4 -H volunteers for over 15 years. Two respondents $(1.4 \%)$ chose not to answer this question.

Table 24

Number of Years 4-H Club Leaders have Served as a 4-H Volunteer

\begin{tabular}{lcc}
\hline Categories & $N$ & $\%$ \\
\hline $0-2$ years & 8 & 5.6 \\
$3-5$ years & 33 & 22.9 \\
6-10 years & 32 & 22.2 \\
$11-15$ years & 15 & 10.4 \\
Over 15 years & 54 & 37.5 \\
Missing Value & 2 & 1.4 \\
\hline Total & 144 & 100.0 \\
\hline
\end{tabular}


Age. Four respondents $(2.8 \%)$ reported their age fell in the $22-29$ years category (see Table 25). The category, 30-39 years, had 28 respondents (19.4\%) and the category, 40-49 years, had 54 respondents (37.5\%). Thirty-four respondents (23.6\%) reported their age fell in the 50-59 years category while 19 respondents (13.2\%) reported their ages as over 60 years. Five respondents (3.5\%) declined to answer this question.

Table 25

Age of 4-H Club Leaders

\begin{tabular}{lcc}
\hline Categories & $N$ & $\%$ \\
\hline $22-29$ years & 4 & 2.8 \\
$30-39$ years & 28 & 19.4 \\
$40-49$ years & 54 & 37.5 \\
$50-59$ years & 34 & 23.6 \\
Over 60 years & 19 & 13.2 \\
Missing Value & 5 & 3.5 \\
\hline Total & 144 & 100.0 \\
\hline
\end{tabular}

Years as a 4-H Member. Forty-seven respondents (32.6\%) reported that they were never a 4-H member (see Table 26). The categories, 1-2 years as a 4-H member and 3-5 years as a $4-\mathrm{H}$ member, both had 11 respondents $(7.6 \%)$ each. Twenty respondents (13.9\%) reported that they had been a 4-H member for 6-8 years and 15 respondents (10.4\%) had been 4-H members for 9-10 years. Thirty-five respondents (24.3\%) reported having been $4-\mathrm{H}$ members for over 10 years. Five respondents (3.5\%) decided not to answer this question. 
Table 26

Number of Years 4-H Club Leaders were a 4-H Member

\begin{tabular}{lcc}
\hline Categories & $N$ & $\%$ \\
\hline Never a member & 47 & 32.6 \\
1-2 years & 11 & 7.6 \\
3-5 years & 11 & 7.6 \\
6-8 years & 20 & 13.9 \\
9-10 years & 15 & 10.4 \\
Over 10 years & 35 & 24.3 \\
Missing Value & 5 & 3.5 \\
\hline Total & 144 & 99.9 \\
\hline
\end{tabular}

Training Sessions During the Past Twelve Months. Forty-one respondents (28.5\%) have attended no 4-H training sessions during the past twelve months while 73 respondents (50.7\%) have attended 1 to $24-\mathrm{H}$ training sessions during the past twelve months (see Table 27). Twenty-two respondents (15.3\%) reported having attended 3 to 5 4-H training sessions during the past twelve months and three respondents (2.1\%) replied that they had attended 6 to $84-\mathrm{H}$ training sessions during the past twelve months. Five respondents (3.5\%) did not reply to this question. 
Table 27

Number of Training Sessions Attended by 4-H Club Leaders During the Past Twelve Month

\begin{tabular}{lcc}
\hline Categories & $N$ & $\%$ \\
\hline None & 41 & 28.5 \\
$1-2$ & 73 & 50.7 \\
$3-5$ & 22 & 15.3 \\
$6-8$ & 3 & 2.1 \\
Missing Value & 5 & 3.5 \\
\hline Total & 144 & 100.1 \\
\hline
\end{tabular}

Average Hours Volunteered To 4-H During A Month. Seventy-five respondents (52.1\%) reported that they spent, on average, 0 to 10 hours a month volunteering for $4-\mathrm{H}$ (see Table 28). Forty-four respondents (30.6\%) reported that on average, they spent 11 to 25 hours a month volunteering for $4-\mathrm{H}$ while 13 respondents $(9.0 \%)$ replied that on average, they spent 26 to 50 hours a month volunteering for $4-\mathrm{H}$. Three respondents (2.1\%) indicated they volunteered between 51 to 100 hours a month and one respondent $(0.7 \%)$ responded to having spent on average over 250 hours a month volunteering for 4H. Eight respondents (5.6\%) declined answering this question. 
Table 28

Average Number of Hours per Month Volunteered by 4-H Club Leaders

\begin{tabular}{lcc}
\hline \multicolumn{1}{c}{ Categories } & $N$ & $\%$ \\
\hline $0-10$ hours & 75 & 52.1 \\
$11-25$ hours & 44 & 30.6 \\
$26-50$ hours & 13 & 9.0 \\
$51-100$ hours & 3 & 2.1 \\
Over 250 hours & 1 & 0.7 \\
Missing Value & 8 & 5.6 \\
\hline Total & 144 & 100.1 \\
\hline
\end{tabular}

Club Sizes. In describing the number of 4-H members in the clubs of the respondents, the minimum number of club members was 5 while the maximum number of club members was 101 (see Table 29). The mean number of club members reported by the respondents was 24.64 with a standard deviation of 15.10 . The respondents reported 0 as the minimum number of other volunteer leaders involved with their clubs and 33 as the maximum number (see Table 29). The mean number of other volunteer leaders was 4.48 with a standard deviation of 4.53 .

Table 29

Average Club Size Reported by 4-H Club Leaders

\begin{tabular}{lcccc}
\hline & Min & Max & $M$ & $S D$ \\
\hline $\begin{array}{l}\text { What is the number of 4-H members in your club } \\
\text { How many other volunteer leaders are involved with your }\end{array}$ & 5 & 101 & 24.64 & 15.10 \\
club & & 33 & 4.48 & 4.53 \\
\hline
\end{tabular}




\section{CHAPTER V}

\section{Summary, Conclusions, and Recommendations}

The purpose of this study was to determine why individuals volunteer to be a 4- $\mathrm{H}$ leader, the attitudes volunteers have towards the different types of training they are offered in their individual county and across the state of West Virginia, the training needs of 4-H volunteers, and the methods by which 4-H volunteers prefer to receive training. Objectives of the Study

The following objectives for the study were to identify:

1. The reasons volunteers give their time to the 4-H program;

2. The attitudes $4-\mathrm{H}$ volunteers have toward $4-\mathrm{H}$ volunteer training activities;

3. The types of 4-H volunteer training opportunities that are available to volunteers;

4. The topics in which $4-\mathrm{H}$ volunteers have received training and what topics they want to receive additional training;

5. The amount of training that each $4-\mathrm{H}$ volunteer has participated in and the amount of training in which each volunteer is willing to participate; and

6. The preferred methods of receiving 4-H volunteer training in 4-H.

\section{Summary}

The respondents' reasons for becoming a 4-H volunteer vary. Out of the 27 statements provided that may be reasons for volunteering, over $90 \%$ of the respondents expressed some level of agreement with 13 of them. Respondents agree that they volunteer with 4-H, because they want to help people; they like associating with youth; they want to have influence on how young people learn and grow; they want to improve 
their community; it is a way to express their caring and concern for others; it gives them a chance to meet other volunteers; they want to learn new things; they want to teach and lead others; they like being involved in the leadership of the 4-H program; they feel needed in the program; they have goals for what they want to accomplish as a volunteer; they like to receive feedback from Extensions staff, parents, and 4-H members about how they are doing; and it is a task they can do well.

Over $75 \%$ of the respondents expressed some level of agreement that 21 of the statements were reasons they became a volunteer. In addition to the 13 items previously mentioned, eight new reasons were added to the list. These reasons include wanting to be with their child(ren) in the 4-H program; preferring to work with groups of people rather than alone; they like the challenge of the task; it is a constructive use of their leisure time; they like being involved in making decisions and program planning; they like to be responsible for 4-H programs; it was important that people like them; and they feel an obligation to 4-H, because of what it had done for them.

Less than $50 \%$ of the respondents expressed agreement that three items were reasons for becoming a 4-H volunteer. These volunteers don't have a problem saying "no" when asked. They don't volunteer to receive recognition or gain experience and skills which might lead to employment.

When asked to response about reasons for volunteer training, there were five statements that $90 \%$ of the respondents expressed some level of agreement to. Respondents stated that training is important to becoming a volunteer club leader. Reasons for attending training sessions were to improve their knowledge about 4- $\mathrm{H}$, improve their leadership abilities, and obtain new activities for use in their clubs. They 
also plan to attend more training sessions in the future. An additional two statements can be added to the list of reasons for volunteer training based on over $75 \%$ of the respondents expressing some form of agreement. Respondents attend volunteer training sessions to improve their knowledge of youth and to improve their personal growth and development. Less than $50 \%$ of the respondents expressed some level of agreement with three of the statements. The respondents do not feel that training is only for persons with no 4-H background or new volunteers. Respondents also feel that training sessions are beneficial to club leaders.

Respondents had received training on many $4-\mathrm{H}$ training topics. Over $75 \%$ of the respondents have received training on the use of the 4-H name and emblem, the purpose of $4-\mathrm{H}$, working with youth, and parliamentary procedure. Between $74 \%$ and $50 \%$ of the respondents had received training on most of the topics, 35 out of 47 (excludes "other" categories). Less the $50 \%$ of the respondents have received training in eight topics. This includes individual and family resources; natural resources and environment; recruitment of 4-H leaders; building exhibits; animal science; communication arts and sciences; plant science and crops; and mechanical science. Six of these eight were subject matter topics, which pertain to the subject matter found in the project books 4-H members complete.

Respondents wanted more training on many of the topics. Over $65 \%$ of the respondents wanted training in program planning, events-opportunities for members, and understanding youth. Between $64 \%$ and $50 \%$ of the respondents wanted more training on 35 of the 47 topics. Less than $50 \%$ of the respondents wanted more training in natural resources agenda building; communication arts and sciences; use of the 4-H name and 
emblem; working with adults; purpose of 4-H; plant science and crops; animal science; and mechanical science.

Respondents were asked to determine what methods of training delivery they preferred. By simply answering "yes" or "no," the top five methods of training delivery were hands-on participation, single county meeting, handbook, newsletter, and workshop-multiple topic. When the respondents were asked to rank their "yes" responses in order from 1 to 5 with 1 being the best method, the top five methods were single county meeting, multicounty meetings, hands-on participation, handbook, and internet based course. The two lowest ranked methods of training delivery by "yes" and "no" answering were statewide meetings and pre-recorded audio and they were the only methods to receive less than $50 \%$ approval. These two methods remained on the bottom when ranked and presentation or lecture was added to the bottom three methods.

When it came to how frequently respondents felt they should participation in training sessions, as needed was the respondents' favorite choice followed by quarterly, annually, and semi-annually. Monthly and bi-monthly training were not received as good frequencies with less than $10 \%$ of the respondents approving. Over $50 \%$ of the respondents preferred that county staff or a state specialist present the training to a group. Less the $15 \%$ of the respondents agreed that 1 to 1 with county staff and 1 to 1 with another leader were good methods of delivery.

When respondents were asked what the most important thing learned at a volunteer training session, their responses varied greatly. Most were only expressed by one individual. Of the responses given by more than one individual the most frequent answer was that the respondents have received no club leader training. Other responses 
that came up more than once include programs and activities; new ideas; how to hold meetings; use of logo and 4-H emblem; how to take care of 4-H funds; and how to deal with different abilities and needs.

Respondents were asked to express what areas volunteer training should address more. The answers to this question also varied. The most frequent response was training to address the 4-H project books whether to help complete them or to review new and revised projects. Respondents also want to know more about recruitment of both members and volunteers. Once they have been recruited, respondents want to know how to keep them involved. Other topics that were given by multiple respondents were program ideas; inclusion/acceptance of all youth/leaders; events and opportunities for leaders and/or members; and controlling disruptive (challenge) children.

Demographically, the majority of respondents were females in their 40s to 50s who have been $4-\mathrm{H}$ volunteers for at least 3 years. These respondents were involved in the program for at least 6 years. During the past twelve months, the majority of the respondents have attended up to 2 training sessions and dedicated up to 25 hours a month to $4-\mathrm{H}$ volunteering. The average club has 25 members with 5 volunteer leaders.

\section{Conclusions}

West Virginia 4-H volunteers have multiple reasons for being a 4-H volunteer club leader. Many volunteers like helping people and working with youth. Others want to have an influence how young people learn and grow. However, most volunteers do not volunteer to gain status in their community or because they want people to like them. 4-H volunteer club leaders volunteer to improve their community. 
4-H volunteer club leaders in West Virginia feel that training is important in becoming a leader. Reasons that they attend training include improving their knowledge about youth and 4-H as well as improving their leadership skills. Volunteer especially attend training to obtain new activities for their clubs. Volunteers feel that training is for everyone regardless of if they have a 4-H background or not. Also training should be for all leaders, new or old. Volunteers feel that training is beneficial and they hope to attend more training in the future.

Volunteers may have received training in the past on club mechanics, leadership roles, public relations, volunteer leader training, subject matter, leisure education, and skills 4-H youth learn, but most the volunteers would like to received more training in these areas. The only section to receive lower percentages in wanting training was subject matter. Some areas that the most volunteers wanted more training in were program planning, events and opportunities for members and leaders, and understanding youth.

Most volunteers prefer to have hands-on participation during training. Single county meetings were the best group for volunteers. They also prefer handbooks and newsletters. If a workshop is held, volunteers more often would like for them to cover multiple topics. West Virginia 4-H volunteers like pre-recorded audio training the least. Out of the preferred training methods, single county meetings were picked as the top choice with multicounty meetings as the second chose. Hands-on participation is another top choice as well as handbooks.

West Virginia 4-H volunteer club leaders prefer to participate in training sessions as needed but will participate in them as frequently as four times a year. Most volunteers 
felt that monthly and even bi-monthly was too frequent for training sessions. The volunteers prefer that county staff address a group during training session or a state specialist delivers the training. One on one with county staff or even another leader were not delivery methods that the volunteers favored.

Some of the most important things that West Virginia 4-H volunteer club leaders have learned in training includes programs, activities, new ideas, holding meetings, use of logo, use of 4-H emblem, caring for 4-H funds, paper work, listening to others, legal issues, dealing with different abilities and needs, learning from others, making a difference, organization, charter requirements, getting along with others, involving everyone, and about new projects. However, many volunteers have never attended a 4-H training session. There are several topics that volunteers wish training would address need. It is important that training covers projects in the future. Volunteers want to have more training on new projects and how to complete projects. Volunteers also want to know more training on how to recruitment new members and leaders. Then they want to know how to keep them involved once they join. Other topics that volunteers want to cover in training includes program ideas, inclusion of all youth and leaders, events and opportunities for leaders and members, controlling disruptive children, understanding youth, teaching tools and techniques, money issues, community service, demonstrations, exhibits, public speaking, and activities for clubs.

The majority of the volunteer leaders in West Virginia are female. Nearly all of the respondents to this survey have been a 4-H volunteer for at least 3 years with over one-third having volunteered for over 15 years. Therefore, most of these volunteers are willing to continue their services to the $4-\mathrm{H}$ once they have started. The age of most of 
the respondents was older too. Nearly three-fourths of the respondents were at least 40 years or over. Consequently most of the $4-\mathrm{H}$ volunteer club leaders in West Virginia must be older, more experienced volunteers with the 4-H program. However, experienced volunteers aren't necessarily former 4-H members. A lot of West Virginia 4-H volunteer club leaders were never members of $4-\mathrm{H}$. On the other hand, if they were a 4-H member, they were involved in 4-H for at least 6 years $(48.6 \%)$.

Most volunteers have attended 1 to 2 training sessions during the past twelve months. On average, West Virginia 4-H club leaders are spending 0-25 hours a month volunteering to $4-\mathrm{H}$ with the majority volunteering 10 hours or less. The average $4-\mathrm{H}$ club has about 25 members and 5 leaders in the state of West Virginia.

\section{Recommendations}

The data collected from this survey should be taken into consideration when county extension agents and extension specialists plan future volunteer training sessions within their own county or across the state. A follow up survey that consisted of part of the original instrument could be sent a year later to see how the volunteers' responses have changed due to changes made by extension agents in their training sessions that reflect the results from the first survey. The population should be expanded to include all of the counties in the state of West Virginia. This would allow the researcher to determine if comparable feedback exists across the state.

The data from the section 4-H volunteer training participation and needs could be analyzed differently. The "yes" and "no" respondents from the prior training questions could be separately analyzed to see which respondents who replied "yes" wanted more training in these areas while the "no" respondents could be analyzed to see who wants to 
be trained on those topics and who doesn't feel it is necessary. The data could also be compared non 4-H member to former 4-H members (regardless of years involved) to see if their reasons for volunteering differed or if their needs and wants in training sessions differ.

The title of the section with questions 78 to 76 should be changed to reflect that subject matter is referring to the $4-\mathrm{H}$ project subject matter. These questions received low "yes" responses to wanting training. However on question 113, an open end question that asked respondents what areas they wished volunteer training addressed more, many of the answers given pertained to project books. 


\section{REFERENCES}

Ary, D., Jacobs, L. C., \& Razavieh, A. (2002). Introduction to Research in Education. Belmont, CA: Wadsworth/Thomson Learning.

Boggs, B. (1986). Major distinguishing characteristics of successful adult volunteer 4-H club leaders. Unpublished Master's thesis, West Virginia University, Morgantown.

Boyd, B. L., Herring, D. R., \& Briers, G. E. (1992). Developing life skills in youth. Journal of Extension. [Online], 30 (4). Available at: http://www.joe.org/joe/1992winter/a4.html

Cook, M. J., Kiernan, N. E., \& Ott, H. R (1986). 4-H volunteer training-Who needs it! Journal of Extension [Online], 24 (3). Available at: http://www.joe.org/joe/1986fall/a4.html

Cress, C. A. (2002). Does participation in a 4-H club make a difference in a young person's life? National 4-H Headquarters. [Online]. Available at: http://www.national4-hheadquarters.gov/library/4-H-YES.pdf

Culp, K. (1996), Identifying continuing and non-continuing adult 4-h volunteers: how have they evolved over time? Journal of Agricultural Education [Online], (37) 4. Available at: http://pubs.aged.tamu.edu/jae//pdf/vol37/37-04-44.pdf 
Culp, K., McKee, R. K., \& Nestor, P. (2005). Demographic differences of 4-h volunteers, agents, and state volunteerism specialists: implications for volunteer administration. . Journal of Extension [Online], 43 (4). Available at: http://www.joe.org/joe/2005august/a2.shtml

Dillman, D. A. (2000). Mail and internet surveys: The tailored design method ( $7^{\text {th }}$ ed.). New York: John Wiley \& Sons, Inc.

Henderson, K. A. (1980) Motivating the adult 4-H volunteer. Journal of Extension [Online], 19 (1). Available at: http://www.joe.org/joe/1981january/81-1-a4.pdf

Kwarteng, J. A., Smith, K. L., \& Miller, L. E. (1988). Ohio 4-H agents' and volunteer leaders' perceptions of the volunteer leadership development program. The Journal of Agricultural Education [Online], 29 (2). Available at: http://pubs.aged.tamu.edu/jae/pdf/Vol29/29-02-55.pdf

Lowry, K. S. (1987) Assessing the educational training needs of volunteer 4-H leaders in Indiana. Unpublished Master's thesis, Purdue University, West Lafayette.

National 4-H Council. (2007). 4-H youth development: An overview. [Online] Available at: http://www.fourhcouncil.edu/pv_obj_cache/pv_obj_id_67DEE17C0C72A37211E 30C35209E08E396F50000

National 4-H Headquarters (2006). 4-H history. [Online] Available at: http://www.national4-hheadquarters.gov/about/4h_history.htm 
Nestor, P. et al. (2006) Identifying the core competencies necessary for volunteers in the state of West Virginia (replication of national study) Developing the 4-H VRK model: 4-H youth development volunteer research \& knowledge base. Formative Report. (Unpublished manuscript)

Robinson, J. P., Shaver, P. R., \& Wrightsman, L. S. (1991). Criteria for scale selection and evaluation. In J.P. Robinson, P. R. Shaver, \& L. S. Wrightsman (Eds.). Measures of personality and social psychological attitudes (pp. 1-16) New York: Academic Press.

Smith, K. L. \& Bigler N. M. (1985). Keeping 4-H Volunteer Leaders. Journal of Extension [Online], 23 (2). Available at: http://www.joe.org/joe/1985summer/a3.html

VanWinkle R., Busler, S., Bowman, S. R., \& Manoogian, M. (2002). Adult volunteer development: Addressing the effectiveness of training new 4-H leaders. Journal of Extension [Online]. 40(6). Available at: http://www.joe.org/joe/2002december/a4.shtml 
APPENDICES 
APPENDIX A

Cover Letter for Initial Mailing 
July 10, 2007

Dear Community 4-H Club Program Volunteer Leader:

You are a vital part of the $4-\mathrm{H}$ program. You run meetings, plan activities, and conduct camping programs just to name a few things. Without volunteers such as you, 4$\mathrm{H}$ programs wouldn't be able to run. Extension agents count on numerous volunteers to "teach throughout the 4-H world what those before have taught them." Because you serve such a vital role in the 4-H organization it is important to determine your perspectives on volunteering in the organization as well as the ways the organization can help you do your job better.

I am Jennifer Post, a graduate student in Agricultural and Extension Education, and under the direction of my advisor, Dr. Harry N. Boone, Jr., we are conducting this study to determine the attitudes volunteers have towards the training they are offered in their individual county and across the state of West Virginia. The study will also identify training needs of 4-H volunteers. The results of this study will be used to prepare a thesis to partially fulfill the requirements for a Master of Science Degree in Agricultural and Extension Education. By determining how training has a significant difference in volunteer's lives, extension agents can adapt their training methods to better prepare the volunteers that will assist the $4-\mathrm{H}$ programs.

Participation in this research study is completely voluntary and all information you provide will be held as confidential as possible. The survey should only take about ten minutes to complete and your response to the survey is crucial to the success of the study. You may skip any question you are not comfortable answering. You will notice a code number at the top left of the return envelope. This code will be used to identify nonrespondents for follow-up and will be destroyed before the data are analyzed. Survey results will be reported in a summary format and individual responses will not be identifiable.

Place the completed questionnaire in the enclosed postage-paid self-addressed return envelope and drop in the mail. Please return your completed questionnaire before August 1, 2007. Thank you in advance for your assistance with this research effort. We sincerely appreciate your time and effort.

Sincerely:

Jennifer Post

Graduate Student
Harry N. Boone, Jr., Ph.D

Associate Professor 
APPENDIX B

Data Collection Instrument 


\title{
Attitudes of 4-H Club Leaders Toward Volunteer Training in West Virginia
}

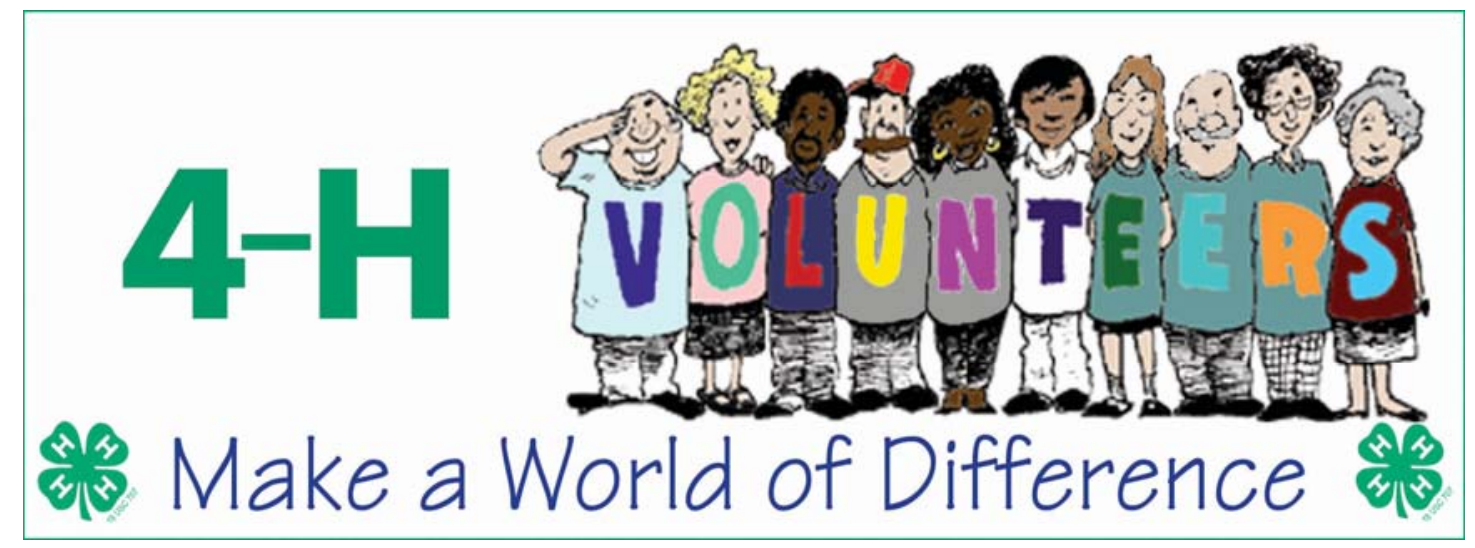

\author{
Jennifer Post \\ Graduate Student \\ Agricultural and Extension Education \\ Davis College of Agriculture, Forestry, and Consumer Sciences \\ West Virginia University \\ Morgantown, WV 26506
}




\section{Attitudes of 4-H Club Leaders Toward Volunteer Training in West Virginia}

\section{Reasons for Becoming a 4-H Volunteer}

Instructions: Using the following Likert scale, rate the following statement on why you became a volunteer in the 4-H organization. Indicate your opinion by circling the letters that best corresponds to your response: $S D$-Strongly Disagree, MD-Moderately Disagree, SD - Slightly Disagree, SA - Slightly Agree, MA - Moderately Agree, and SA Strongly Agree.

\begin{tabular}{|c|c|c|c|c|c|c|}
\hline Reason & 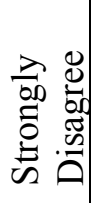 & 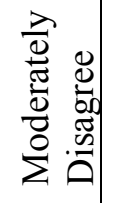 & 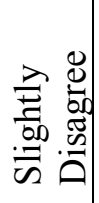 & 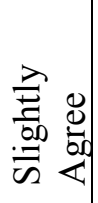 & 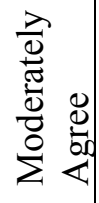 & 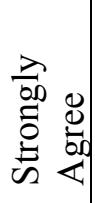 \\
\hline $\begin{array}{l}\text { 1. I am a 4-H volunteer because I want to be with } \\
\text { my child(ren) in the } 4-\mathrm{H} \text { program. }\end{array}$ & SD & MD & SD & SA & MA & SA \\
\hline $\begin{array}{l}\text { 2. I am a 4-H volunteer because I like helping } \\
\text { people. }\end{array}$ & SD & $\mathrm{MD}$ & SD & SA & MA & SA \\
\hline $\begin{array}{l}\text { 3. I am a } 4-\mathrm{H} \text { volunteer because I like associating } \\
\text { with youth. }\end{array}$ & $\mathrm{SD}$ & $\mathrm{MD}$ & $\mathrm{SD}$ & SA & MA & SA \\
\hline $\begin{array}{l}\text { 4. I am a 4-H volunteer because I want to have } \\
\text { influence on how young people learn and } \\
\text { grow. }\end{array}$ & $\mathrm{SD}$ & $\mathrm{MD}$ & SD & SA & MA & SA \\
\hline $\begin{array}{l}\text { 5. I volunteer in } 4-\mathrm{H} \text { because it is a way to } \\
\text { improve my community. }\end{array}$ & SD & $\mathrm{MD}$ & $\mathrm{SD}$ & SA & MA & SA \\
\hline $\begin{array}{l}\text { 6. I am a 4-H volunteer because it is a way I can } \\
\text { express my caring and concern for others. }\end{array}$ & $\mathrm{SD}$ & MD & $\mathrm{SD}$ & SA & MA & SA \\
\hline $\begin{array}{l}\text { 7. Volunteering in } 4-\mathrm{H} \text { gives me a chance to meet } \\
\text { other volunteers. }\end{array}$ & $\mathrm{SD}$ & $\mathrm{MD}$ & $\mathrm{SD}$ & SA & MA & SA \\
\hline $\begin{array}{l}\text { 8. I am a 4-H volunteer because I want to learn } \\
\text { new things. }\end{array}$ & $\mathrm{SD}$ & $\mathrm{MD}$ & SD & SA & MA & SA \\
\hline $\begin{array}{l}\text { 9. As a 4-H volunteer, I prefer to work with } \\
\text { groups of people rather than alone. }\end{array}$ & SD & MD & SD & SA & MA & SA \\
\hline
\end{tabular}




\begin{tabular}{|c|c|c|c|c|c|c|}
\hline Reason & 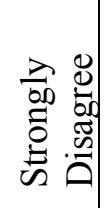 & 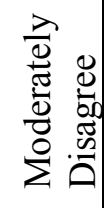 & 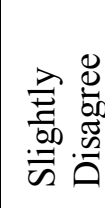 & 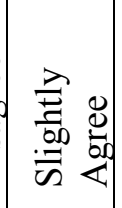 & 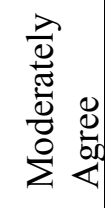 & 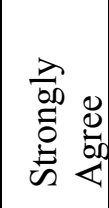 \\
\hline $\begin{array}{l}\text { 10. I am a 4-H volunteer because I want to teach } \\
\text { and lead others. }\end{array}$ & SD & MD & SD & SA & MA & SA \\
\hline $\begin{array}{l}\text { 11. I like being involved in the leadership of the } \\
4-\mathrm{H} \text { program. }\end{array}$ & SD & MD & SD & SA & MA & SA \\
\hline $\begin{array}{l}\text { 12. I am a 4-H volunteer because I like the } \\
\text { challenge of the task. }\end{array}$ & SD & MD & SD & SA & MA & SA \\
\hline $\begin{array}{l}\text { 13. I am a 4-H volunteer because I feel needed in } \\
\text { the program. }\end{array}$ & SD & MD & SD & SA & MA & SA \\
\hline $\begin{array}{l}\text { 14. As a 4-H volunteer, it is important to me that } \\
\text { people like me. }\end{array}$ & SD & MD & SD & SA & MA & SA \\
\hline $\begin{array}{l}\text { 15. As a 4-H volunteer, I have goals for what I } \\
\text { want to accomplish as a volunteer. }\end{array}$ & SD & MD & SD & SA & MA & SA \\
\hline $\begin{array}{l}\text { 16. I am a 4-H volunteer because it is a } \\
\text { constructive use of my leisure time. }\end{array}$ & SD & MD & $\mathrm{SD}$ & SA & MA & SA \\
\hline $\begin{array}{l}\text { 17. As a volunteer, I like to receive feedback from } \\
\text { Extension staff, parents, and 4-H members } \\
\text { about how I am doing. }\end{array}$ & SD & MD & SD & SA & MA & SA \\
\hline $\begin{array}{l}\text { 18. I am a 4-H volunteer because I like to be } \\
\text { involved in making decisions and program } \\
\text { planning. }\end{array}$ & SD & MD & SD & SA & MA & SA \\
\hline $\begin{array}{l}\text { 19. I am a 4-H volunteer because it is a task I can } \\
\text { do well. }\end{array}$ & SD & MD & SD & SA & MA & SA \\
\hline $\begin{array}{l}\text { 20. As a 4-H volunteer, I enjoy being able to "do } \\
\text { my own thing." }\end{array}$ & SD & MD & SD & SA & MA & SA \\
\hline $\begin{array}{l}\text { 21. I am a 4-H volunteer because I feel an } \\
\text { obligation to 4-H because of what it has done } \\
\text { for me. }\end{array}$ & SD & MD & SD & SA & MA & SA \\
\hline $\begin{array}{l}\text { 22. I volunteer in 4-H because I like to be } \\
\text { responsible for } 4-\mathrm{H} \text { programs. }\end{array}$ & SD & MD & SD & SA & MA & SA \\
\hline
\end{tabular}




\begin{tabular}{|c|c|c|c|c|c|c|}
\hline Reason & 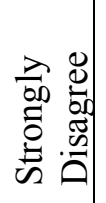 & 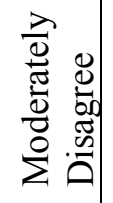 & 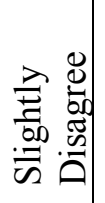 & 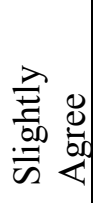 & 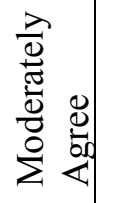 & 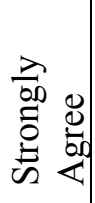 \\
\hline $\begin{array}{l}\text { 23. I receive status in my community because I am } \\
\text { a } 4-\mathrm{H} \text { volunteer. }\end{array}$ & SD & $\mathrm{MD}$ & SD & SA & MA & SA \\
\hline $\begin{array}{l}\text { 24. I am a 4-H volunteer because I can't say "no" } \\
\text { when I am asked. }\end{array}$ & SD & $\mathrm{MD}$ & SD & SA & MA & SA \\
\hline $\begin{array}{l}\text { 25. I am a 4-H volunteer because I like to receive } \\
\text { recognition for being a volunteer. }\end{array}$ & $\mathrm{SD}$ & $\mathrm{MD}$ & SD & SA & MA & SA \\
\hline $\begin{array}{l}\text { 26. I am a 4-H volunteer because I want to have } \\
\text { influence over others. }\end{array}$ & $\mathrm{SD}$ & $\mathrm{MD}$ & $\mathrm{SD}$ & SA & MA & SA \\
\hline $\begin{array}{l}\text { 27. I am a 4-H volunteer in order to gain } \\
\text { experience and skills which might lead to } \\
\text { employment. }\end{array}$ & SD & MD & SD & SA & MA & SA \\
\hline
\end{tabular}

\section{Attitudes toward 4-H Volunteer Training}

Instructions: Using the following Likert scale, rate your opinion on each of the volunteer training issues. Indicate your opinion by circling the letters that best corresponds to your response: SD - Strongly Disagree, $M D$ - Moderately Disagree, SD - Slightly Disagree, SA - Slightly Agree, MA - Moderately Agree, and SA - Strongly Agree.

\begin{tabular}{|c|c|c|c|c|c|c|}
\hline Issue & 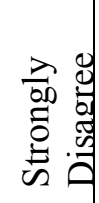 & 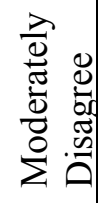 & 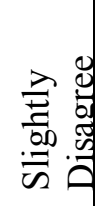 & 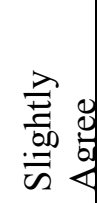 & 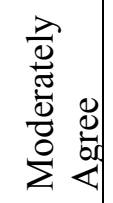 & 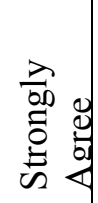 \\
\hline $\begin{array}{l}\text { 28. Training is important to becoming a volunteer } \\
\text { club leader. }\end{array}$ & SD & MD & SD & SA & MA & SA \\
\hline $\begin{array}{l}\text { 29. Training is only for persons who have no } 4-\mathrm{H} \\
\text { background. }\end{array}$ & $\mathrm{SD}$ & MD & SD & SA & MA & SA \\
\hline 30. Training is only for new volunteers. & SD & MD & SD & SA & MA & SA \\
\hline $\begin{array}{l}\text { 31. The amount of training my county offers is } \\
\text { adequate for learning how to be a club leader. }\end{array}$ & SD & MD & SD & SA & MA & SA \\
\hline
\end{tabular}




\begin{tabular}{|l|l|l|l|l|l|l|}
\hline $\begin{array}{l}\text { Issue } \\
\begin{array}{l}\text { 32. Yearly volunteer training sessions would not be } \\
\text { beneficial to club leaders. }\end{array}\end{array}$ & SD & $\mathrm{MD}$ & $\mathrm{SD}$ & $\mathrm{SA}$ & $\mathrm{MA}$ & $\mathrm{SA}$ \\
\hline $\begin{array}{l}\text { 33. I attend volunteer training sessions for my } \\
\text { personal growth and development. }\end{array}$ & $\mathrm{SD}$ & $\mathrm{MD}$ & $\mathrm{SD}$ & $\mathrm{SA}$ & $\mathrm{MA}$ & $\mathrm{SA}$ \\
\hline $\begin{array}{l}\text { 34. I attend volunteer training sessions to improve } \\
\text { my knowledge about youth. }\end{array}$ & & & & & & \\
\hline $\begin{array}{l}\text { 35. I attend volunteer training sessions to improve } \\
\text { my knowledge about 4-H. }\end{array}$ & $\mathrm{SD}$ & $\mathrm{MD}$ & $\mathrm{SD}$ & $\mathrm{SA}$ & $\mathrm{MA}$ & $\mathrm{SA}$ \\
\hline $\begin{array}{l}\text { 36. I attend volunteer training sessions to improve } \\
\text { my leadership abilities. }\end{array}$ & $\mathrm{MD}$ & $\mathrm{SD}$ & $\mathrm{SA}$ & $\mathrm{MA}$ & $\mathrm{SA}$ \\
\hline $\begin{array}{l}\text { 37. I attend volunteer training sessions to improve } \\
\text { my attitudes about 4-H. }\end{array}$ & & $\mathrm{SD}$ & $\mathrm{MD}$ & $\mathrm{SA}$ & $\mathrm{MA}$ & $\mathrm{SA}$ \\
\hline $\begin{array}{l}\text { 38. I attend volunteer training sessions to obtain new } \\
\text { activities for use in my club. }\end{array}$ & $\mathrm{SD}$ & $\mathrm{SA}$ & $\mathrm{MA}$ & $\mathrm{SA}$ \\
\hline $\begin{array}{l}\text { 39. I plan to attend more training sessions in the } \\
\text { future. }\end{array}$ & $\mathrm{SD}$ & $\mathrm{MD}$ & $\mathrm{SD}$ & $\mathrm{SA}$ & $\mathrm{MA}$ & $\mathrm{SA}$ \\
\hline
\end{tabular}

\section{4-H Volunteer Training Participation and Needs}

Instructions: For each of the items below, indicate if you have participated in training on the topic and if you would like additional training on the subject. Designate your answers by circling the appropriate response.

\begin{tabular}{|l|c|c|c|c|}
\hline Training Topic & \multicolumn{2}{|c|}{$\begin{array}{c}\text { I have had prior } \\
\text { training in this area. }\end{array}$} & \multicolumn{2}{c|}{$\begin{array}{c}\text { I want training } \\
\text { sessions on this topic }\end{array}$} \\
\hline Club mechanics & & & & \\
\hline 40. Program planning & Yes & No & Yes & No \\
\hline 41. Club organization & Yes & No & Yes & No \\
\hline 42. Agenda building & Yes & No & Yes & No \\
\hline 43. Committee functions & Yes & No & Yes & No \\
\hline
\end{tabular}




\begin{tabular}{|c|c|c|c|c|}
\hline \multirow{2}{*}{ Training Topic } & \multicolumn{2}{|c|}{$\begin{array}{c}\text { I have had prior } \\
\text { training in this area. }\end{array}$} & \multicolumn{2}{c|}{ sessiont training } \\
\hline 44. The 4-H Club meeting & Yes & No & Yes & No \\
\hline 45. Parliamentary procedure & Yes & No & Yes & No \\
\hline 46. Events/opportunities for members & Yes & No & Yes & No \\
\hline 47. Events/opportunities for leaders & Yes & No & Yes & No \\
\hline 48. Other: & Yes & No & Yes & No \\
\hline Leadership roles & & & & \\
\hline 49. Recruitment of 4-H members & Yes & No & Yes & No \\
\hline 50. Recruitment of 4-H leaders & Yes & No & Yes & No \\
\hline 51. Working with teen leaders & Yes & No & Yes & No \\
\hline 52. Role of the 4-H leader & Yes & No & Yes & No \\
\hline 53. Understanding youth & Yes & No & Yes & No \\
\hline 54. Other: & Yes & No & Yes & No \\
\hline Public relations & & & & \\
\hline 55. Building exhibits & Yes & No & Yes & No \\
\hline 56. Demonstrations & Yes & No & Yes & No \\
\hline 57. Public speaking & Yes & No & Yes & No \\
\hline 58. Working with adults & Yes & No & Yes & No \\
\hline 59. Working with youth & Yes & No & Yes & No \\
\hline 60. Community service & Yes & No & Yes & No \\
\hline 61. Other: & Yes & No & Yes & No \\
\hline Volunteer leader training & & & & \\
\hline 62. Purpose of 4-H & Yes & No & Yes & No \\
\hline 63. Use of the 4-H name and emblem & Yes & No & Yes & No \\
\hline 64. Teaching tools and techniques & Yes & No & Yes & No \\
\hline 65. Developing 4-H programs & Yes & No & Yes & No \\
\hline 66. Handling funds in 4-H organizations & Yes & No & Yes & No \\
\hline 67. Other: & Yes & No & Yes & No \\
\hline Subject matter & Yes & No & Yes & No \\
\hline 68. Animal science & & & & \\
\hline & & & & \\
\hline & & & & \\
\hline
\end{tabular}




\begin{tabular}{|l|c|c|c|c|}
\hline Training Topic & \multicolumn{2}{|c|}{$\begin{array}{l}\text { I have had prior } \\
\text { training in this area. }\end{array}$} & \multicolumn{2}{c|}{$\begin{array}{c}\text { I want training } \\
\text { sessions on this topic }\end{array}$} \\
\hline 69. Plant science and crops & Yes & No & Yes & No \\
\hline 70. Mechanical science & Yes & No & Yes & No \\
\hline 71. Natural resources and environment & Yes & No & Yes & No \\
\hline $\begin{array}{l}\text { 72. Leadership and community } \\
\text { involvement }\end{array}$ & Yes & No & Yes & No \\
\hline 73. Health and safety & Yes & No & Yes & No \\
\hline 74. Individual and family resources & Yes & No & Yes & No \\
\hline 75. Communication arts and sciences & Yes & No & Yes & No \\
\hline 76. Other: & Yes & No & Yes & No \\
\hline Leisure education & & & & \\
\hline 77. Recreation & Yes & No & Yes & No \\
\hline 78. Song leading & Yes & No & Yes & No \\
\hline 79. Camping & Yes & No & Yes & No \\
\hline 80. Other: & Yes & No & Yes & No \\
\hline Skills 4-H youth learn & & & & \\
\hline 81. Decision making & Yes & No & Yes & No \\
\hline 82. Social responsibility & Yes & No & Yes & No \\
\hline 83. Valuing diversity & Yes & No & Yes & No \\
\hline 84. Leadership skills & Yes & No & Yes & No \\
\hline 85. Problem-solving & Yes & No & Yes & No \\
\hline 86. Relationship-building & Yes & No & Yes & No \\
\hline 87. Critical thinking & Yes & No & Yes & No \\
\hline 88. Communication & Yes & No & Yes & No \\
\hline 89. Conflict resolution & Yes & No & Yes & No \\
\hline 90. Goal-setting & Yes & No & Yes & No \\
\hline 91. Planning & Yes & No & Yes & No \\
\hline 92. Personal safety & & Yes & No \\
\hline 93. Other: & & & Yes \\
\hline
\end{tabular}




\section{Desired Methods and/or Delivery Techniques of Receiving 4-H Volunteer Training}

Instructions: For each of the items below, indicate by circling the appropriate response, your willingness to participate in the training method and/or delivery techniques. Then rank your top five preferences for training methods.

\begin{tabular}{|l|c|c|c|}
\hline Method or Delivery Technique & \multicolumn{2}{|c|}{$\begin{array}{c}\text { I am willing to } \\
\text { participate in this } \\
\text { method of training. }\end{array}$} & $\begin{array}{c}\text { My top five training } \\
\text { method(s) would be: } \\
\text { (rank 1 to 5) }\end{array}$ \\
\hline 94. Handbook & Yes & No & \\
\hline 95. Single county meeting & Yes & No & \\
\hline 96. Multicounty meetings & Yes & No & \\
\hline 97. Regional meetings & Yes & No & \\
\hline 98. Statewide meetings & Yes & No & \\
\hline 99. Internet based course & Yes & No & \\
\hline 100. Weekend training conference & Yes & No & \\
\hline 101. Workshop - single topic & Yes & No & \\
\hline 102. Workshop - multiple topic & Yes & No & \\
\hline 103. Extension bulletin & Yes & No & \\
\hline 104. Newsletter & Yes & No & \\
\hline 105. Pre-recorded video & Yes & No & \\
\hline 106. Pre-recorded audio & Yes & No & \\
\hline 107. Presentation or lecture & Yes & No & \\
\hline 108. Group discussion & Yes & No & \\
\hline 109. Hands-on participation & Yes & No & \\
\hline 110. Other: & Yes & No & \\
\hline
\end{tabular}


111. How frequently would you be willing to participate in training activities? (check all that apply)
a. Monthly
b. Bi-monthly
c. Quarterly
d. Semi-annually
e. Annually
f. As needed

112. Who would you prefer to deliver the training(s)? (check all that apply)

a. County staff to a group

b. 1 to 1 with county staff

c. 1 to 1 with another leader

d. Program teams

e. State specialist

f. Other (please specify:

113. What is the most important thing you have learned at a volunteer training session?

114. What area(s) do you wish volunteer training addressed more?

115. What is your gender?
a. Male
b. Female

116. How many years have you been a $4-\mathrm{H}$ volunteer?
a. 0-2 years
b. 3-5 years
c. 6-10 years
d. 11-15 years
e. over 15 years 
117. What is your age?

a. $18-21$ years

b. 22-29 years

c. 30-39 years

d. 40-49 years

e. 50-59 years

f. over 60 years

118. How many years were you a 4-H member?

a. Never a member

b. 1-2 years

c. 3-5 years

d. 6-8 years

e. 9-10 years

f. over 10 years

119. How many training sessions have you attended during the past twelve months?

a. None

b. $1-2$

c. $3-5$

d. $6-8$

e. $9-10$

f. Over 10

120. On the average, how many hours do you volunteer for 4-H during a month?

a. $0-10$ hours

b. $11-25$ hours

c. $26-50$ hours

d. $51-100$ hours

e. $101-150$ hours

f. $151-200$ hours

g. $201-250$ hours

h. Over 250 hours

121. What is the number of $4-\mathrm{H}$ members in your club?

122. How many other volunteer leaders are involved with your club? 
Comments:

If you have questions about the survey, please contact me at: jshirey@mix.wvu.edu or call (304) 598-5646.

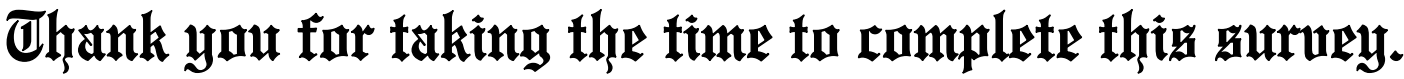


APPENDIX C

Cover Letter for Second Mailing 
August 3, 2007

Dear Community 4-H Club Program Volunteer Leader:

On July 10, we sent you a questionnaire about your activities as a 4-H volunteer. As of today, we have not received your reply. We have enclosed a second copy of the survey and hope you will take the time to complete and return. If you have already returned the first survey there is no need to complete this one, we sincerely appreciate your participation.

You are a vital part of the 4-H program. You run meetings, plan activities, and conduct camping programs just to name a few things. Without volunteers such as you, 4$\mathrm{H}$ programs wouldn't be able to run. Extension agents count on numerous volunteers to "teach throughout the 4-H world what those before have taught them." Because you serve such a vital role in the 4-H organization it is important to determine your perspectives on volunteering in the organization as well as the ways the organization can help you do your job better.

I am Jennifer Post, a graduate student in Agricultural and Extension Education, and under the direction of my advisor, Dr. Harry N. Boone, Jr., we are conducting this study to determine the attitudes volunteers have towards the training they are offered in their individual county and across the state of West Virginia. The study will also identify training needs of $4-\mathrm{H}$ volunteers. The results of this study will be used to prepare a thesis to partially fulfill the requirements for a Master of Science Degree in Agricultural and Extension Education. By determining how training has a significant difference in volunteer's lives, extension agents can adapt their training methods to better prepare the volunteers that will assist the 4-H programs.

Participation in this research study is completely voluntary and all information you provide will be held as confidential as possible. The survey should only take about ten minutes to complete and your response to the survey is crucial to the success of the study. You may skip any question you are not comfortable answering. You will notice a code number at the top left of the return envelope. This code will be used to identify nonrespondents for follow-up and will be destroyed before the data are analyzed. Survey results will be reported in a summary format and individual responses will not be identifiable.

Place the completed questionnaire in the enclosed postage-paid self-addressed return envelope and drop in the mail. Please return your completed questionnaire before August 15, 2007. Thank you in advance for your assistance with this research effort. We sincerely appreciate your time and effort.

Sincerely:

Jennifer Post

Graduate Student
Harry N. Boone, Jr., Ph.D. Associate Professor 
APPENDIX D

Follow-Up Postcard 
On July 10, 2007, I sent you a questionnaire about the attitudes Community 4-H Club Program Volunteer Leaders have towards the training they are offered in their individual county and across the state of West Virginia. A second copy of the questionnaire was mailed on August 6, 2007. As of today, I have not received your reply. Because you serve such a vital role in the 4-H organization it is important to determine your perspectives on volunteering in the organization as well as the ways the organization can help you do your job better. Your responses are vital to the success of this project, so please take the time to complete and return it by September 5, 2007. If you have already returned the survey, please disregard this card. Thank you for your contribution to my study.

If you have any questions, please contact me at:

\section{Jennifer Post}

Agricultural and Extension Education

Davis College of Agriculture, Forestry, and Consumer Sciences

West Virginia University

2054 Agricultural Sciences Building

P.O. Box 6108

Morgantown, WV 26506

304-293-4832 ext. 4481

jennifershireypost@yahoo.com 


\section{APPENDIX E}

Important Things Learned at Volunteer Training Session 
Table E

Most Important Thing Learned at a Volunteer Training Session

\begin{tabular}{|c|c|c|}
\hline & \multicolumn{2}{|c|}{ Yes } \\
\hline & $N$ & $\%$ \\
\hline No club leader training & 6 & 4.2 \\
\hline Programs and activities & 4 & 2.8 \\
\hline New ideas & 4 & 2.8 \\
\hline How to hold meetings & 4 & 2.8 \\
\hline Use of logo and 4-H emblem & 3 & 2.1 \\
\hline How to take care of $4-\mathrm{H}$ funds & 3 & 2.1 \\
\hline How to deal with different abilities and needs & 3 & 2.1 \\
\hline We all have similar problems & 2 & 1.4 \\
\hline The Paper Work & 2 & 1.4 \\
\hline $\begin{array}{l}\text { The importance of a mentor and a positive role-model in the lives } \\
\text { of our youth }\end{array}$ & 2 & 1.4 \\
\hline Roles & 2 & 1.4 \\
\hline Not able to recall & 2 & 1.4 \\
\hline Listen to others & 2 & 1.4 \\
\hline Legal Issues & 2 & 1.4 \\
\hline Learn from others & 2 & 1.4 \\
\hline Leadership & 2 & 1.4 \\
\hline Keeping an open mind & 2 & 1.4 \\
\hline I can make a difference & 2 & 1.4 \\
\hline How to involve everyone & 2 & 1.4 \\
\hline How to get along and work with others & 2 & 1.4 \\
\hline
\end{tabular}




\begin{tabular}{|c|c|c|}
\hline & \multicolumn{2}{|c|}{ Yes } \\
\hline & $N$ & $\%$ \\
\hline How to be organized & 2 & 1.4 \\
\hline How important volunteerism can be & 2 & 1.4 \\
\hline Charter Requirements for $4-\mathrm{H}$ & 2 & 1.4 \\
\hline About new projects & 2 & 1.4 \\
\hline To resolve conflicts & 1 & 0.7 \\
\hline $\begin{array}{l}\text { To remember we are volunteers and what and how we act and } \\
\text { react has a lasting impression on our children and community }\end{array}$ & 1 & 0.7 \\
\hline Think before you speak & 1 & 0.7 \\
\hline $\begin{array}{l}\text { Things to watch for that indicates hazing, bullying, and gang } \\
\text { activity }\end{array}$ & 1 & 0.7 \\
\hline They're fun and you can learn a lot & 1 & 0.7 \\
\hline $\begin{array}{l}\text { The ways we as leaders can help our youth reach into themselves } \\
\text { and bring out their best }\end{array}$ & 1 & 0.7 \\
\hline $\begin{array}{l}\text { The volunteer leaders weekend-I previously attended were very } \\
\text { invigorating and helped keep me involved }\end{array}$ & 1 & 0.7 \\
\hline The more you teach them the more they want to learn & 1 & 0.7 \\
\hline $\begin{array}{l}\text { The Dedication of the leaders, volunteers, the young people, the } \\
\text { entire 4-H Dept }\end{array}$ & 1 & 0.7 \\
\hline $\begin{array}{l}\text { That our current training method is ineffective (PowerPoint } \\
\text { presentation, little discussion) }\end{array}$ & 1 & 0.7 \\
\hline Take notes & 1 & 0.7 \\
\hline Stress management for teens & 1 & 0.7 \\
\hline Shooting Sports Instruction & 1 & 0.7 \\
\hline Safety_risk assessment & 1 & 0.7 \\
\hline Rules & 1 & 0.7 \\
\hline
\end{tabular}




\begin{tabular}{|c|c|c|}
\hline & \multicolumn{2}{|c|}{ Yes } \\
\hline & $N$ & $\%$ \\
\hline Risk management at shooting sports & 1 & 0.7 \\
\hline Respect and Joy from the children & 1 & 0.7 \\
\hline Refreshing of $4-\mathrm{H}$ goals & 1 & 0.7 \\
\hline Public speaking techniques & 1 & 0.7 \\
\hline Not much & 1 & 0.7 \\
\hline New Policies and Regulations & 1 & 0.7 \\
\hline New methods to get information across & 1 & 0.7 \\
\hline More about topic & 1 & 0.7 \\
\hline Making sure everyone knows they are appreciated & 1 & 0.7 \\
\hline Leader meeting & 1 & 0.7 \\
\hline $\begin{array}{l}\text { It takes the entire team to work together in order to have a } \\
\text { successful } 4-\mathrm{H} \text { program }\end{array}$ & 1 & 0.7 \\
\hline $\begin{array}{l}\text { I've learned how to make heritage crafts_-baskets, drawings, } \\
\text { etc... }\end{array}$ & 1 & 0.7 \\
\hline I'm not alone & 1 & 0.7 \\
\hline I like to network-I meet others and ask questions & 1 & 0.7 \\
\hline How to work with Children & 1 & 0.7 \\
\hline How to plan and conduct an effective $4-\mathrm{H}$ camp & 1 & 0.7 \\
\hline How to lead and instruct youth & 1 & 0.7 \\
\hline How to have 4-H projects completed & 1 & 0.7 \\
\hline How to deal with other personality types & 1 & 0.7 \\
\hline How to deal with kids and attitudes & 1 & 0.7 \\
\hline $\begin{array}{l}\text { How fulfilling it is to be part of a living, working, thriving body } \\
\text { of volunteers! }\end{array}$ & 1 & 0.7 \\
\hline
\end{tabular}




\begin{tabular}{|c|c|c|}
\hline & \multicolumn{2}{|c|}{ Yes } \\
\hline & $N$ & $\%$ \\
\hline History of 4-H & 1 & 0.7 \\
\hline Games & 1 & 0.7 \\
\hline Fundraising ideas for clubs & 1 & 0.7 \\
\hline Depend on the people that actually show up to help & 1 & 0.7 \\
\hline Dealing with campers & 1 & 0.7 \\
\hline Community Involvement & 1 & 0.7 \\
\hline Communication & 1 & 0.7 \\
\hline Children come first, as always & 1 & 0.7 \\
\hline Changes in 4-H & 1 & 0.7 \\
\hline Camp volunteer & 1 & 0.7 \\
\hline Camp Safety Training & 1 & 0.7 \\
\hline Be willing to change & 1 & 0.7 \\
\hline Be patience & 1 & 0.7 \\
\hline Ask questions & 1 & 0.7 \\
\hline Animal livestock interests & 1 & 0.7 \\
\hline
\end{tabular}


APPENDIX F

Areas Volunteer Training Addressed More 
Table F

Areas Volunteer Training Should Address More

\begin{tabular}{|c|c|c|}
\hline & \multicolumn{2}{|c|}{ Yes } \\
\hline & $N$ & $\%$ \\
\hline Project books--help for completion & 9 & 6.3 \\
\hline Program ideas & 7 & 4.9 \\
\hline Recruitment of volunteers & 5 & 3.5 \\
\hline Keeping parents involved in $4-\mathrm{H}$ & 4 & 2.8 \\
\hline Recruitment of members & 3 & 2.1 \\
\hline Project books--new \& revised & 3 & 2.1 \\
\hline Keeping kids involved in $4-\mathrm{H}$ & 3 & 2.1 \\
\hline Inclusion/Acceptance of all youth/leaders & 3 & 2.1 \\
\hline Events and Opportunities for leaders and/or members & 3 & 2.1 \\
\hline Controlling disruptive (challenge) children & 3 & 2.1 \\
\hline Understanding youth & 2 & 1.4 \\
\hline Teaching tools and techniques & 2 & 1.4 \\
\hline Money Issues & 2 & 1.4 \\
\hline $\begin{array}{l}\text { How to ask people nicely to do things - instead of bribing or } \\
\text { demanding }\end{array}$ & 2 & 1.4 \\
\hline Demonstrations, exhibits, and public speaking & 2 & 1.4 \\
\hline Community Service & 2 & 1.4 \\
\hline Activities for clubs & 2 & 1.4 \\
\hline Ways to help build confidence/self-esteem in boys and girls & 1 & 0.7 \\
\hline $\begin{array}{l}\text { Ways to get more leaders to participate ABOVE the club level } \\
\text { (county, regional, state) }\end{array}$ & 1 & 0.7 \\
\hline
\end{tabular}




\begin{tabular}{|c|c|c|}
\hline & \multicolumn{2}{|c|}{ Yes } \\
\hline & $N$ & $\%$ \\
\hline $\begin{array}{l}\text { Volunteers do not get money-could we get coupons to state parks } \\
\text { or something for volunteering? }\end{array}$ & 1 & 0.7 \\
\hline Today's issues faced by our youth & 1 & 0.7 \\
\hline Time management & 1 & 0.7 \\
\hline The program is about the kids and not the leaders & 1 & 0.7 \\
\hline The paper work & 1 & 0.7 \\
\hline $\begin{array}{l}\text { The National \& State's position on backing up volunteers in tough } \\
\text { decision making situations }\end{array}$ & 1 & 0.7 \\
\hline $\begin{array}{l}\text { The importance of programs of interest at regular meetings } \\
\text { accompanied with devotions and some traditional songs }\end{array}$ & 1 & 0.7 \\
\hline The details of how things should be run-the boring & 1 & 0.7 \\
\hline Teen leader activities & 1 & 0.7 \\
\hline Skills for 4-Hers & 1 & 0.7 \\
\hline Resources & 1 & 0.7 \\
\hline Regulations & 1 & 0.7 \\
\hline Recruitment (general) & 1 & 0.7 \\
\hline Public relations - advertise the good of $4-\mathrm{H}$ & 1 & 0.7 \\
\hline Project workshops & 1 & 0.7 \\
\hline Project books & 1 & 0.7 \\
\hline Policies and procedure & 1 & 0.7 \\
\hline Planning and management & 1 & 0.7 \\
\hline Organization & 1 & 0.7 \\
\hline Officer training in clubs & 1 & 0.7 \\
\hline Manners \& Kindness & 1 & 0.7 \\
\hline
\end{tabular}




\begin{tabular}{|c|c|c|}
\hline & \multicolumn{2}{|c|}{ Yes } \\
\hline & $N$ & $\%$ \\
\hline Looking more at youth not in traditional family & 1 & 0.7 \\
\hline Liabilities \& Risks to volunteers & 1 & 0.7 \\
\hline Keeping meetings/children orderly \& Fun & 1 & 0.7 \\
\hline It's all about the youth NOT the volunteers!!! & 1 & 0.7 \\
\hline $\begin{array}{l}\text { Interpersonal skills, team building, proactive leadership, } \\
\text { throughout entire group }\end{array}$ & 1 & 0.7 \\
\hline Information to "un-4-Hed" parents and volunteers & 1 & 0.7 \\
\hline $\begin{array}{l}\text { I would love to see } 4-\mathrm{H} \text { branch out in more outdoor recreational } \\
\text { camping activities such as tent camping, hiking trips, etc... }\end{array}$ & 1 & 0.7 \\
\hline $\begin{array}{l}\text { I wish that WVU would have all their information together before } \\
\text { trying to pass it on to the counties }\end{array}$ & 1 & 0.7 \\
\hline I wish it would be held more at county levels & 1 & 0.7 \\
\hline How to teach children to deal with bullies & 1 & 0.7 \\
\hline How to deal with impossible parents & 1 & 0.7 \\
\hline How all leaders need to work together & 1 & 0.7 \\
\hline Goals of $4-\mathrm{H}$ & 1 & 0.7 \\
\hline Getting youth ways to juggle all activities and $4-\mathrm{H}$ too & 1 & 0.7 \\
\hline Games and Songs for Camp & 1 & 0.7 \\
\hline $\begin{array}{l}\text { Future planning for further education for our youth (i.e.- college, } \\
\text { vo-tech, job market) }\end{array}$ & 1 & 0.7 \\
\hline Formal Club Leader Training & 1 & 0.7 \\
\hline $\begin{array}{l}\text { Developmentally appropriate abilities for members (Some leaders } \\
\text { aren't aware of age = ability) }\end{array}$ & 1 & 0.7 \\
\hline Dealing with different types of youth & 1 & 0.7 \\
\hline Conflict resolution & 1 & 0.7 \\
\hline
\end{tabular}




\begin{tabular}{lcc}
\hline & \multicolumn{2}{c}{ Yes } \\
& $N$ & $\%$ \\
\hline Club (How to have great club) & 1 & 0.7 \\
Cloverbud activites/projects/crafts etc... & 1 & 0.7 \\
Camp counseling & 1 & 0.7 \\
$\begin{array}{l}\text { Basic life skills in balancing and handling funds and how to pay } \\
\text { bills and budget their money when adults in the own household }\end{array}$ & & 0.7 \\
Annual club goal setting and planning & 1 & 0.7
\end{tabular}


Jennifer Post

\section{Education}

May 2004

Bachelors of Science Degree

Biology

Bridgewater College

Bridgewater, VA 22812

December 2007

Masters of Science Degree

Agricultural and Extension Education

West Virginia University

Morgantown, WV 26506

Work Experience

August 2007-present

Substitute Teacher

Preston County, WV

August 2004-June 2007

High School Science Teacher

Preston High School

Kingwood, WV

\section{Honors and Activities}

Preston High School Teacher of the Month (December 2006)

Outstanding Woman Scholar Education Award presented by Virginia Iota State Organization of Delta Kappa Gamma

Melissa D. Jett Community Service Award 